\title{
Design Considerations For Artificial Lifting Of Enhanced Geothermal System Fluids
}

X. Xie

K. K. Bloomfield

G. L. Mines

G. M. Shook

July 2005

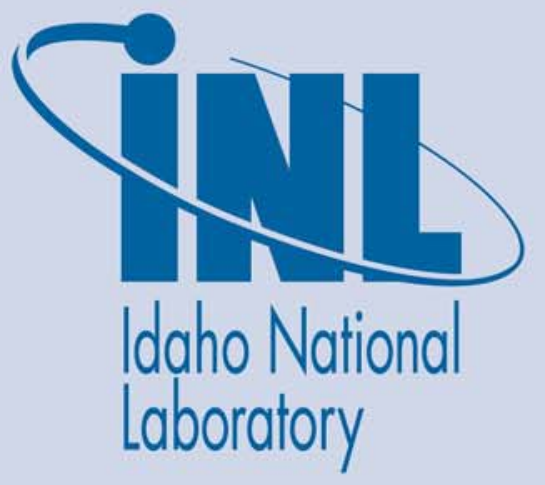

The INL is a U.S. Department of Energy National Laboratory operated by Battelle Energy Alliance 


\title{
Design Considerations for Artificial Lifting of Enhanced Geothermal System Fluids
}

\author{
Xina Xie ${ }^{a}$ \\ Kit K. Bloomfield \\ Gregory L. Mines \\ George M. Shook \\ July 2005

\begin{abstract}
Idaho National Laboratory
Renewable Energy and Power Technologies

Idaho Falls, Idaho 83415
\end{abstract}

Prepared for the

U.S. Department of Energy

Office of Energy Efficiency and Renewable Energy

Under DOE Idaho Operations Office

Contract DE-AC07-05ID14517 



\begin{abstract}
This work evaluates the effect of production well pumping requirements on power generation. The amount of work that can be extracted from a geothermal fluid and the rate at which this work is converted to power increase as the reservoir temperature increases. Artificial lifting is an important issue in this process. The results presented are based on a configuration comprising one production well and one injection well, representing an enhanced geothermal system. The effects of the hydraulic conductivity of the geothermal reservoir, the flow rate, and the size of the production casing are considered in the study. Besides submersible pumps, the possibility of using lineshaft pumps is also discussed.
\end{abstract}




\section{CONTENTS}

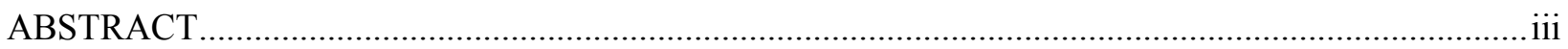

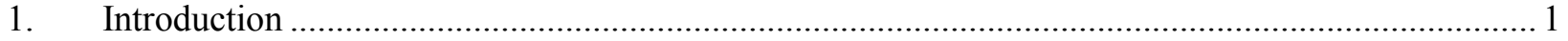

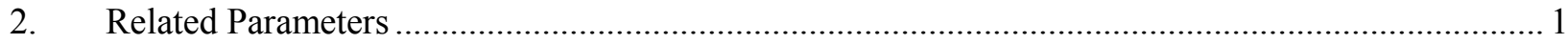

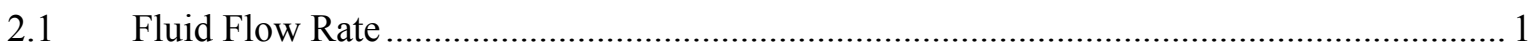

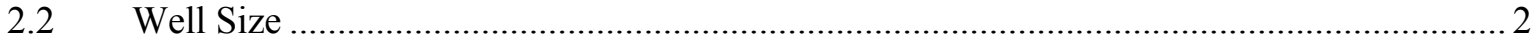

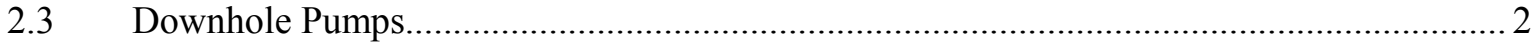

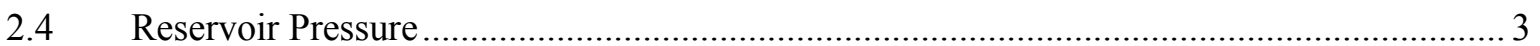

2.5 Bottomhole Pressure of the Production Wells................................................................... 3

2.6 Power Loss in the Production Wellbore ............................................................................. 4

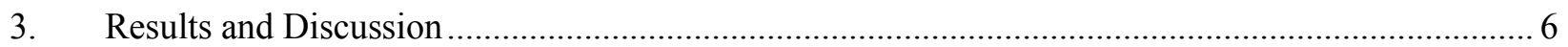

3.1 Constant Gross Power Generation (Submersible Pump) ................................................... 6

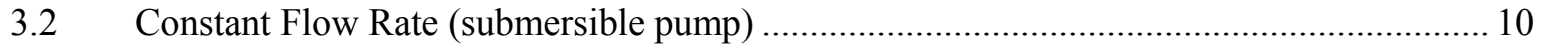

3.3 Constant Gross Power Generation (lineshaft pump) ….................................................. 11

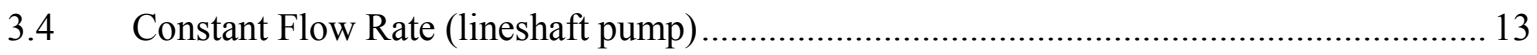

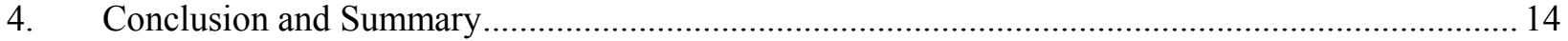

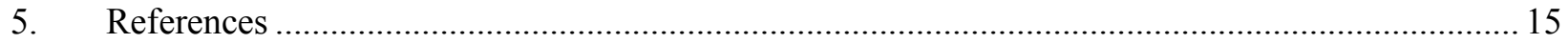

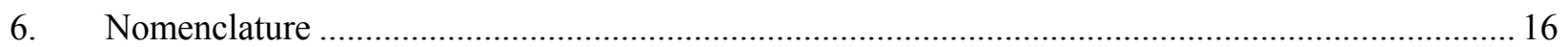

\section{FIGURES}

1. Brine effectiveness and flow rate as functions of fluid temperature. ........................................... 2

2. Bottomhole pressure and well depth at different temperature and hydraulic conductivity.............. 4

3. The effect of well size and hydraulic conductivity on power production. ..................................... 6

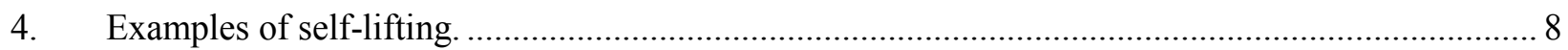

5. Hydrostatic head and pump setting depth at different temperatures. ............................................ 8

6. Friction pressure gradient and pump pressure loss at different temperatures................................ 9

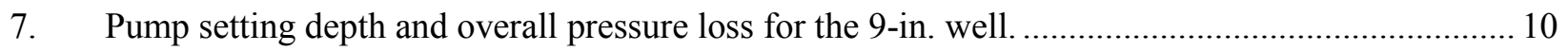

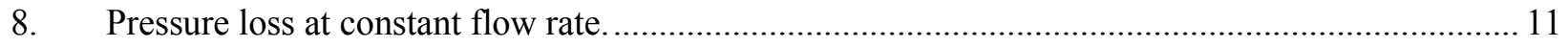

9. Power generation at constant flow rate for different $k h_{r}$ and wells with different sizes................. 11

A-1. The effect of well size and hydraulic conductivity on power production (2.5 MWe)................... 20

A-2. The effect of well size and hydraulic conductivity on power production (7.5 MWe).................. 20

A-3. The effect of well size and hydraulic conductivity on power production (10 MWe)................... 21 
A-4. Hydrostatic head and pump setting depth at different temperature for $2.5 \mathrm{MWe}$.

A-5. Friction pressure gradient and pump pressure loss at different temperature for $2.5 \mathrm{MWe}$.

A-6. Hydrostatic head and pump setting depth at different temperature for $7.5 \mathrm{MWe}$.......................... 22

A-7. Friction pressure gradient and pump pressure loss at different temperature for $7.5 \mathrm{MWe} \ldots \ldots \ldots \ldots . . .23$

A-8. Hydrostatic head and pump setting depth at different temperature for $10 \mathrm{MWe}$...........................23

A-9. Friction pressure gradient and pump pressure loss at different temperature for $10 \mathrm{MWe}$..............24

A-10. Friction pressure gradient and overall pressure loss for constant flow rate (the required flow rate for producing $2.5 \mathrm{MWe}$ at $200^{\circ} \mathrm{C}$ ).

A-11. Power generation and consumption at constant flow rate (the required flow rate for producing 2.5 MWe at $\left.200^{\circ} \mathrm{C}\right)$......

A-12. Friction pressure gradient and overall pressure loss for constant flow rate (the required flow rate for producing $7.5 \mathrm{MWe}$ at $200^{\circ} \mathrm{C}$ ).

A-13. Power generation and consumption at constant flow rate (the required flow rate for producing 7.5 MWe at $\left.200^{\circ} \mathrm{C}\right)$..

A-14. Friction pressure gradient and overall pressure loss for constant flow rate (the required flow rate for producing $10 \mathrm{MWe}$ at $200^{\circ} \mathrm{C}$ ).

A-15. Power generation and consumption at constant flow rate (the required flow rate for producing 10 MWe at $200^{\circ} \mathrm{C}$ ).

\section{TABLES}

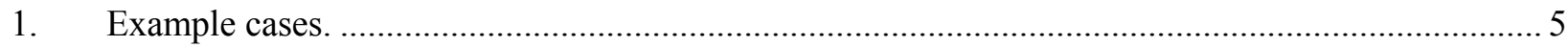

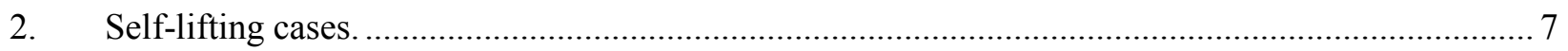

3. Lineshaft pump used for a 2.5-MWe power plant....................................................................... 12

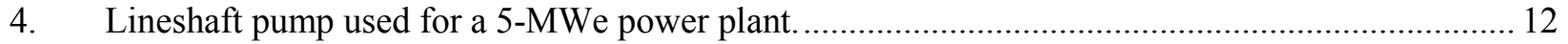

6. A lineshaft pump used for a constant flow rate (required flow rate for a 2.5-MWe power plant at $\left.200^{\circ} \mathrm{C}\right)$

7. Lineshaft pump used for a constant flow rate (required flow rate for a 5-MWe power plant at $\left.200^{\circ} \mathrm{C}\right)$ 


\section{Design Considerations for Artificial Lifting of Enhanced Geothermal System Fluids}

\section{Introduction}

Geothermal energy is a clean source of electricity, and geothermal power generation is becoming a growing market as the limit of petroleum resources and greenhouse gas pollution become international issues. As the world's largest producer of geothermal electricity, the United States generates an average of 15 billion kilowatt hours of power per year, comparable to burning about 25 million barrels of oil or 6 million short tons of coal per year. New geothermal power projects are being pursued in numerous western states, including Alaska, Arizona, California, Hawaii, Idaho, Nevada, New Mexico, Oregon, and Utah (Renewable Energy Access 2005).

Enhanced geothermal system (EGS) performance is controlled by the properties of reservoirs, injection and production wells, and by operational parameters. The costs of geothermal production and injection wells and piping systems are major contributors in the overall cost of generating electrical power from geothermal energy. When a geothermal well cannot sustain natural self-discharge at desired wellhead conditions (pressure and flow rate), downhole pumps are used to minimize the number of production wells required. The setting depth of the pump (and the energy it consumes) is affected by the produced fluid temperature, the size of the production casing, the reservoir supply capability, and the surface (conversion system) flow and pressure requirements.

The study presented herein evaluates the depth of the setting pump depth and the power requirements for a single production well, assuming that the well is producing from an EGS resource. The fluid flow rate from the well, well casing size, and the reservoir pressure are variables. The values used for these parameters are based on prior experience and knowledge. And the study is based on the following assumptions:

- The objective system includes an injection well and a production well; both wells have the same depth; and the flow between the wells in the reservoir is linear

- $\quad$ Only one fluid phase is in the system, i.e., fluid pressure $\geq P_{\text {sat }}$ at any temperature $\left(P_{\text {sat }}\right.$ is the saturation pressure), heat flux is constant in the production well

- The surface pressure of injection well is the saturation pressure of water at the surface temperature.

\section{Related Parameters}

\section{$2.1 \quad$ Fluid Flow Rate}

Based on the assumption that the energy conversion system uses a binary power cycle, a relationship (Equation 1) is developed for the brine effectiveness (be) of the power plant (power output per unit mass of fluid) using work reported by Pritchett (1998) and ongoing cycle analysis activities at the Idaho National Laboratory (INL). The amount of power that can be generated from a given fluid flow rate depends on the temperature of the produced geothermal fluid:

$b e=C+C_{1} T+C_{2} T^{2}+C_{3} T^{3}+C_{4} T^{4}$.

We can calculate the required flow rate in cubic meters per second by using the desired plant output and the brine effectiveness (Figure 1): 


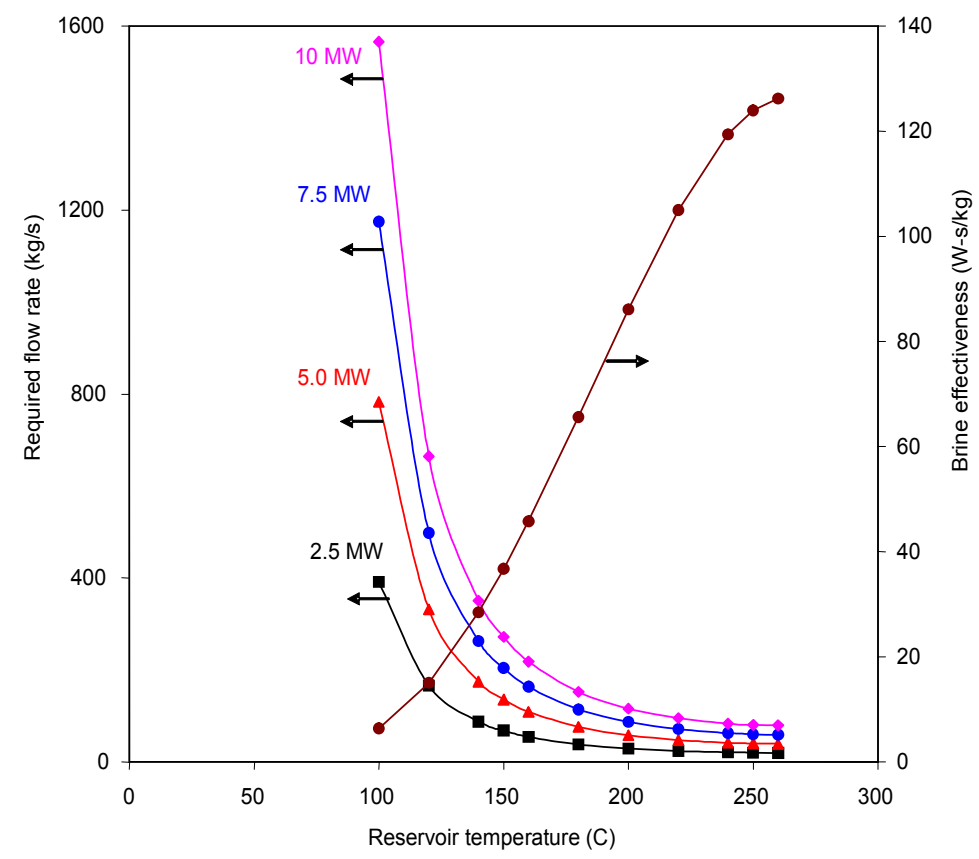

Figure 1. Brine effectiveness and flow rate as functions of fluid temperature.

$q_{i}(T)=\frac{1000}{3.6\left(C+C_{1} T+C_{2} T^{2}+C_{3} T^{3}+C_{4} T^{4}\right)}$

where

$$
\begin{aligned}
& T={ }^{\circ} \mathrm{C} \\
& \text { be }=\mathrm{kW}-\mathrm{s} / \mathrm{kg} \\
& q i(T)=\mathrm{kg} / \mathrm{s} \text { per MWe. }
\end{aligned}
$$

According to Figure 1, fluid flow rate determines the amount of gross power generated by the plant for a given fluid temperature. The net power generated is deducted by pump consumption for artificial lifting, which is related to well size and pump types.

\subsection{Well Size}

Well size refers to the diameter of the production casing. Three well sizes are considered: 6 in. $(152 \mathrm{~mm}), 9$ in. $(229 \mathrm{~mm})$, and 12 in. $(305 \mathrm{~mm})$. These are typical for geothermal applications. The analysis examines the impact of the well size on the power required to deliver fluid to the power plant.

\subsection{Downhole Pumps}

Downhole pumps for geothermal applications are of two kinds: submersible pumps and lineshaft pumps. As shown by the work of Pritchett (1998), the diameter of the column of fluid and well design for calculating frictional pressure gradient $d_{c}$ from pump to wellhead is a function of well casing inside diameter $d_{w}$ :

$d_{c}=3.556+0.59524 d_{w}+0.0004928 d_{w}{ }^{2}$ 
For a lineshaft pump, the fluid column, $d c$, design is the same as for submersible pumps, but the outside diameter of the lube string, $d_{i}$, should also be considered to lubricate the drive shaft that is run from a surface motor to the pump. The lube string is related to the well casing inside diameter, $d_{w}$, by

$d_{i}=0.34 d_{w}$

where $d_{w}, d_{c}$, and $d_{i}$ are in $\mathrm{mm}$.

However, there are some limitations for lineshaft pumps. The maximum depth limit known in a geothermal application is about $426 \mathrm{~m}(1400 \mathrm{ft})$, and the maximum flow rate limit is about $0.1262 \mathrm{~m}^{3} / \mathrm{s}$ (2000 gpm). Therefore, submersible pumps are the only choice when lineshaft pumps cannot be used.

\subsection{Reservoir Pressure}

A temperature gradient of $\Gamma_{T} \cong 0.05^{\circ} \mathrm{C} / \mathrm{m}$ is selected as being typical of hydrothermal reservoirs. This temperature gradient can be used to determine the temperature at a given depth, or it can be used to determine the depth required for a specific temperature. The reservoir depth, $H$, is determined as

$H=\left(T-T_{0}\right) / \Gamma_{T}$

where $T=$ reservoir temperature at depth $\mathrm{H}$, and $T_{0}=$ surface temperature.

The hydrostatic pressure at the bottom of the injection well is

$P_{r}(h)=\int_{0}^{h} \rho(T, P) g d h$.

From Fruier's equation, we have

$\rho=\rho_{0}\left(1+C_{p} \Delta P\right)\left(1-C_{T} \Delta T\right)$.

Substituting Equation (7) into Equation (6) and solving the equation, we have

$P_{r}(h)=P_{0}+\frac{1}{C_{p}}\left[e^{\rho_{0} g C_{P}\left(h-\frac{C_{T}}{2} \Gamma_{T} h^{2}\right)}-1\right]$

where

$$
\begin{aligned}
& P_{0}, \rho_{0}=\text { fluid pressure and density at surface condition } \\
& C_{p} \quad=\text { pressure gradient } \\
& C_{T} \quad=\text { temperature gradient coefficient. }
\end{aligned}
$$

For a typical hydrothermal reservoir, we use $C_{p}=4.64 \times 10^{-7} 1 / \mathrm{KPa}$ or $4.64 \times 10^{-5} 1 / \mathrm{bar}$, and $C_{T}=9 \times 10^{-4} 1 /{ }^{\circ} \mathrm{C}$.

\subsection{Bottomhole Pressure of the Production Wells}

Examples of the bottomhole pressure of the production well at different temperatures and hydraulic conductivity are plotted in Figure 2. Hydraulic conductivity, $k h_{r}$, determines the efficiency at which the reservoir fluid can be transmitted to the production well. Bottomhole pressure, $P_{w f}$, of the production 
well increases as $k h_{r}$ increases. It is reasonable to require that $k h_{r}$ be at least large enough to maintain $P_{w f}>P_{s a t}+1$ to keep fluid pressure above bubble point.

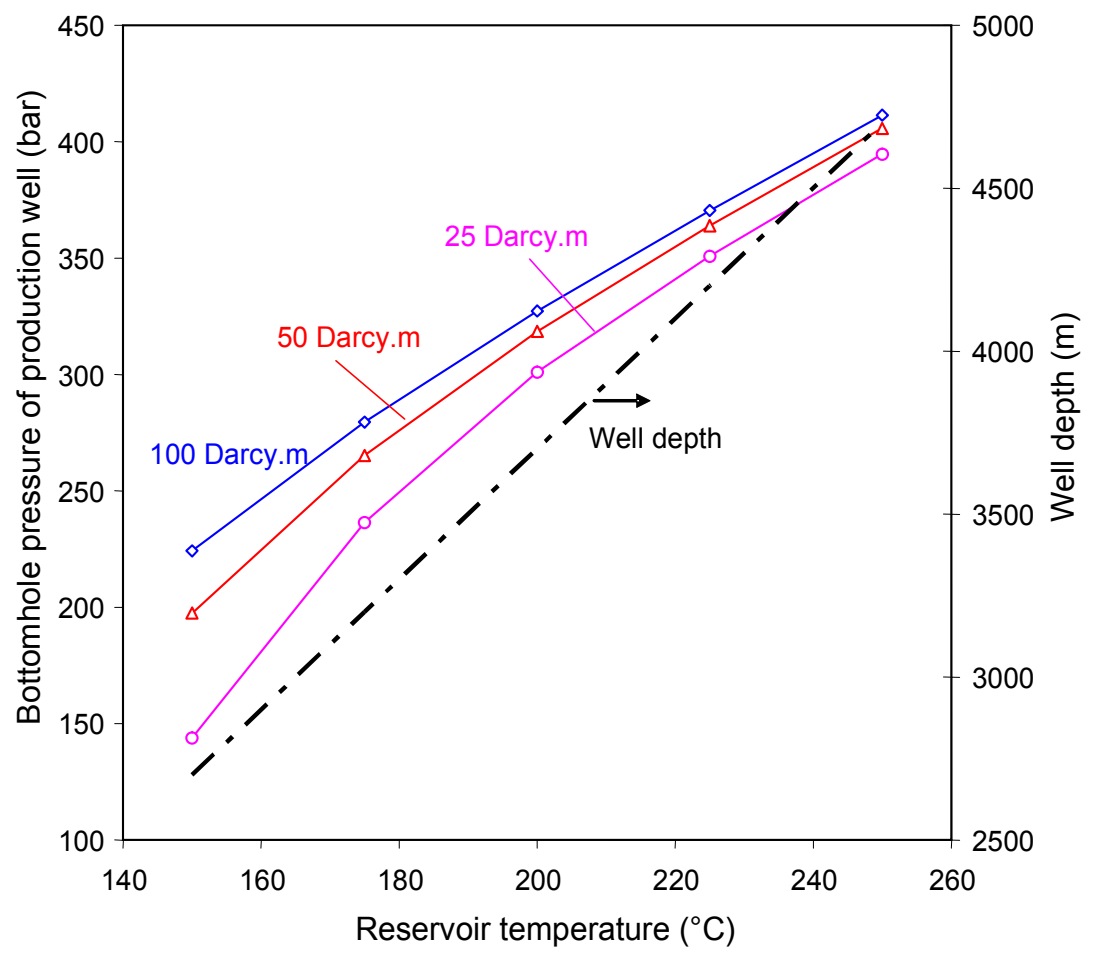

Figure 2. Bottomhole pressure and well depth at different temperature and hydraulic conductivity.

In this study, we assume that the fluid supply is infinite, and the pressure of the reservoir is maintained constant at the bottom of the injection well. The bottomhole pressure of the production well can then be calculated by the Darcy's equation for linear, steady state incompressible flow:

$P_{w f}=P_{r}-\frac{q \mu L}{k h_{r} w}$

where

$$
\begin{aligned}
& k h_{r}=\text { hydraulic conductivity } \\
& L=\text { distance between injection and production wells } \\
& W=\text { reservoir width. }
\end{aligned}
$$

\subsection{Power Loss in the Production Wellbore}

Power loss in the production wellbore is the power necessary to overcome three kinds of forces: hydrostatic force, friction force, and production wellhead pressure. The total pump head is the sum of the hydrostatic force or the true vertical distance from the producing fluid level to the surface, the friction loss in the production string, and wellhead discharge requirements to supply pressurized fluids to the power plant. Power loss caused by hydrostatic force can be calculated by 
$P_{\text {hydro }}=\rho g h q$.

We assume that the volumetric flow rate, $q$, from the reservoir into the wellbore is a constant. Over the range of flow rate considered, the flow in production casing is usually turbulent pipe flow, which means that the dimensionless Reynolds number

$$
N_{\mathrm{Re}}=\rho q d / \mu A>2100 \text {. }
$$

According to Fanning's equation (Beggs 1991), the pressure gradient due to friction is

$$
\left(\frac{d P}{d h}\right)_{f}=\frac{f \rho}{2 d}\left(\frac{q}{A}\right)^{2}
$$

where

$$
\begin{array}{lll}
f & =\text { Darcy-Weisbach friction factor } \\
d & =\text { flow diameter } \\
A=\pi d^{2} / 4 & =\text { flow cross section area. }
\end{array}
$$

For smooth wall pipe in the range $3000<N_{\mathrm{Re}}<3 \times 10^{6}$, the turbulent friction factor can be calculated by

$$
f=0.0056+0.5 N_{\mathrm{Re}}^{-0.32} \text {. }
$$

For lineshaft pump, the Reynolds number is

$$
N_{\mathrm{Re}}=\rho q\left(d_{c}-d_{i}\right) / \mu A \text {. }
$$

The friction pressure gradient is:

$$
\left(\frac{d P}{d h}\right)_{f}=\frac{f \rho}{2\left(d_{c}-d_{i}\right)}\left(\frac{q}{A}\right)^{2}
$$

where $A=\pi\left(d_{c}^{2}-d_{i}^{2}\right) / 4$.

Table 1 lists the related fluid properties at a series of temperatures from 150 to $250^{\circ} \mathrm{C}$. The surface pressure of the production well is confined as $P_{\text {sat }}+1$ at fluid temperature. Two basic cases were calculated. One assumes that the gross power generated from the power plant is constant. The other was to keep the flow rate as a constant and evaluate the well performance at different temperatures and well sizes. The required flow rate at $200^{\circ} \mathrm{C}$ for the specific power output was selected for the calculation.

Table 1. Example cases.

\begin{tabular}{lllllll}
\hline Water temperature $\left({ }^{\circ} \mathrm{C}\right)$ & $15($ surface $)$ & 150 & 175 & 200 & 225 & 250 \\
Water saturation pressure (bar) & 0.01706 & 4.7616 & 8.926 & 15.549 & 25.497 & 39.762 \\
Water viscosity $(\mathrm{Pa} . \mathrm{s})^{\mathrm{a}}$ & 0.00114 & 0.00018 & 0.00016 & 0.00013 & 0.00012 & 0.00011 \\
Water density $\left(\mathrm{kg} / \mathrm{m}^{3}\right)^{\mathrm{a}}$ & 999.04 & 917.0 & 891.52 & 864.66 & 833.04 & 798.88 \\
$\begin{array}{l}\text { Corresponding well depth (m) } \\
\text { Bottomhole pressure of injection }\end{array}$ & 0 & 2700 & 3200 & 3700 & 4200 & 4700 \\
well (bar) & 1.0171 & 251 & 294 & 336 & 377 & 417 \\
Specific net plant electrical & - & 37 & 61 & 86 & 109 & 124 \\
\hline
\end{tabular}


capacity $(\mathrm{KW} / \mathrm{kg} / \mathrm{s})$

a. Calculated with the Winsteam software package.

\section{Results and Discussion}

One set of calculated results for 5-MWe gross power production is presented as the basic case in the following section. Results for gross power production of 2.5, 7.5 and $10 \mathrm{MWe}$ are included in Appendix A. Cases for constant gross power generation, constant flow rate, submersible pump, and lineshaft pump are analyzed.

\subsection{Constant Gross Power Generation (Submersible Pump)}

As shown in Figure 3, when the plant gross power production, $G$, is a constant, the required fluid supply (flow rate) is a function of fluid temperature. The net power production is related to not only fluid temperature, but also to the operational power consumption, which is related to reservoir hydraulic conductivity. The power consumed by hydrostatic force and friction force along the wellbore depend on well size and pump type. One can calculate whether the well size and pump type are feasible in a specific system. Then, the overall cost of drilling and operating geothermal wells and the cost of the output power can be estimated.
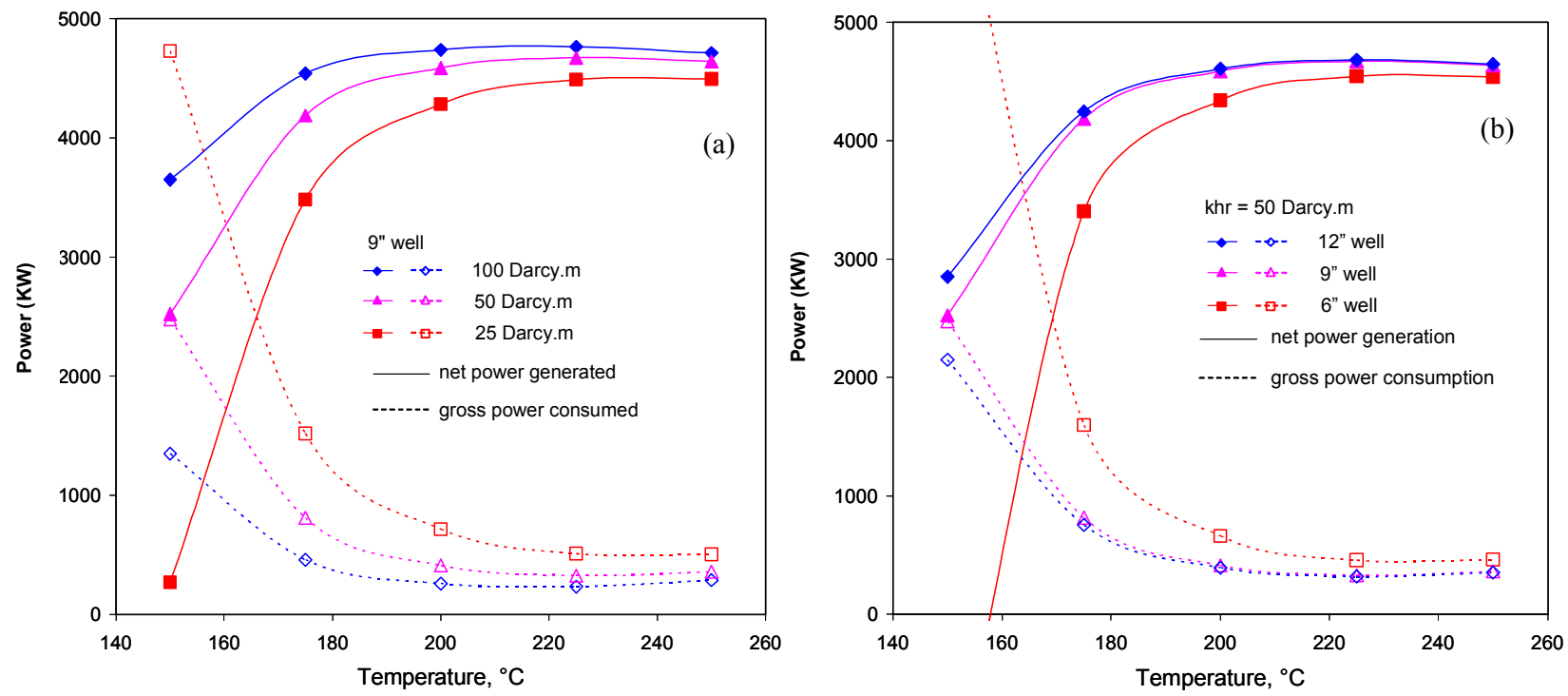

Figure 3. The effect of well size and hydraulic conductivity on power production.

Results calculated for gross power production of $5 \mathrm{MWe}$ are plotted in Figure 3. For the same size well, higher hydraulic conductivity, $k h_{r}$ requires lower power consumption [Figure 3(a)]. It is especially obvious when fluid temperature is $200^{\circ} \mathrm{C}$ or lower. As the temperature increases, the effect of $k h_{r}$ decreases. When $k h_{r}$ is a constant [Figure 3(b)], the 6-in. well consumes the most power, at about $157^{\circ} \mathrm{C}$, and the net power generation is close to zero, which means that all the power generated is consumed [igure 3(b)]. With the small-flow diameter, the flow rate required to maintain the constant power output at the lower temperature range is sufficiently high that the power consumed by the pumps in overcoming the production casing friction losses can exceed the power produced by the surface plant. Therefore, for low-temperature resources, either large-diameter wells are required, or the power output (flow rate) per well is restricted. In the high-temperature range $\left(T \geq 200^{\circ} \mathrm{C}\right)$, the differences in power consumption are very small for all the wells, regardless of diameter. The amount of fluid required is substantially lower at 
the elevated temperatures, which reduces the friction losses in the wells. It is worth noting that power consumed and generated are nearly identical at the high-temperature range, for both 9- and 12-in. wells.

As the fluid temperature increases, much less energy is consumed, and the effect of well size decreases. The 9- and 12-in. wells have very close outcomes, especially when fluid temperature is $150{ }^{\circ} \mathrm{C}$ and above. Generally, net power generation (or gross power consumption) is not very sensitive to well size or temperature change when the reservoir temperature is higher than $200^{\circ} \mathrm{C}$.

Cases for gross power 2.5, 7.5, and 10 MWe are shown in Figures A-1 through A-3 (Appendix A). As the gross power generation increases, the required fluid temperature is higher to keep a positive net power generation. The effect of well size becomes more severe. The 6-in. well may not be an option in many cases, since the power consumed by the lifting operation is more than, or very close to, the gross power generation. However, there is one interesting feature of 2.5-MWe power production (Figures 4 and A1). At $k h_{r}=100$ Darcy.m and fluid temperature of $225^{\circ} \mathrm{C}$ and above, the bottomhole pressure is high enough to overcome friction force and gravity force to lift the fluid to the well head at the required flow rate for both 9- and 12-in. wells. Self-lifting also appears for power production of 5.0 MWe. All the selflifting cases are listed in Table 2, based on the calculation. The hydrostatic head is higher than the well depth, and the pump setting depth goes negative. Therefore, pumps are not necessary; the net power output is the designed power output $(2.5 \mathrm{MWe})$. Self-lifting does not happen within the 6-in. well because of the higher friction force along the well bore. Since the hydrostatic pressure, $P_{h}=\rho g h$, is the same for all the different sizes of wells, the only difference caused by well size is the friction force, which is related to well size and flow rate [Equation (12)].

Table 2. Self-lifting cases.

\begin{tabular}{ccccc}
\hline $\begin{array}{c}\text { Temperature } \\
\left({ }^{\circ} \mathrm{C}\right)\end{array}$ & $\begin{array}{c}\mathrm{kh}_{\mathrm{r}} \\
\text { (Darcy.m) }\end{array}$ & $\begin{array}{c}\text { Well Size } \\
\text { (inch) }\end{array}$ & $\begin{array}{c}\text { Constant Power } \\
\text { Generation (MWe) }\end{array}$ & $\begin{array}{c}\text { Constant Flow } \\
\text { Rate }\left(\mathrm{q}, \mathrm{m}^{3} / \mathrm{s}\right)\end{array}$ \\
\hline 225 & 100 & 9 & 2.5 & - \\
250 & 100 & 9 & 2.5 & - \\
250 & 100 & 9 & - & $\mathrm{q} \mathrm{for} 2.5 \mathrm{MWe}$ at $200^{\circ} \mathrm{C}$ \\
225 & 100 & 12 & 2.5 & - \\
250 & 100 & 12 & 2.5 & - \\
250 & 100 & 12 & - & q for $2.5 \mathrm{MWe}$ at $200^{\circ} \mathrm{C}$ \\
225 & 100 & 9 & 5.0 & - \\
250 & 100 & 9 & 5.0 & - \\
\hline
\end{tabular}




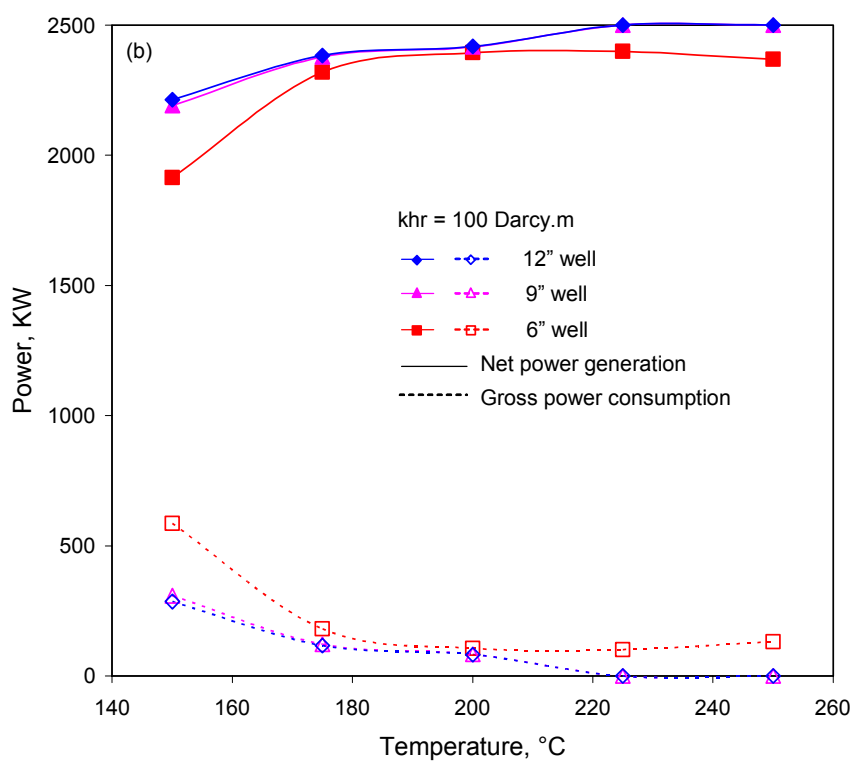

Figure 4. Examples of self-lifting.
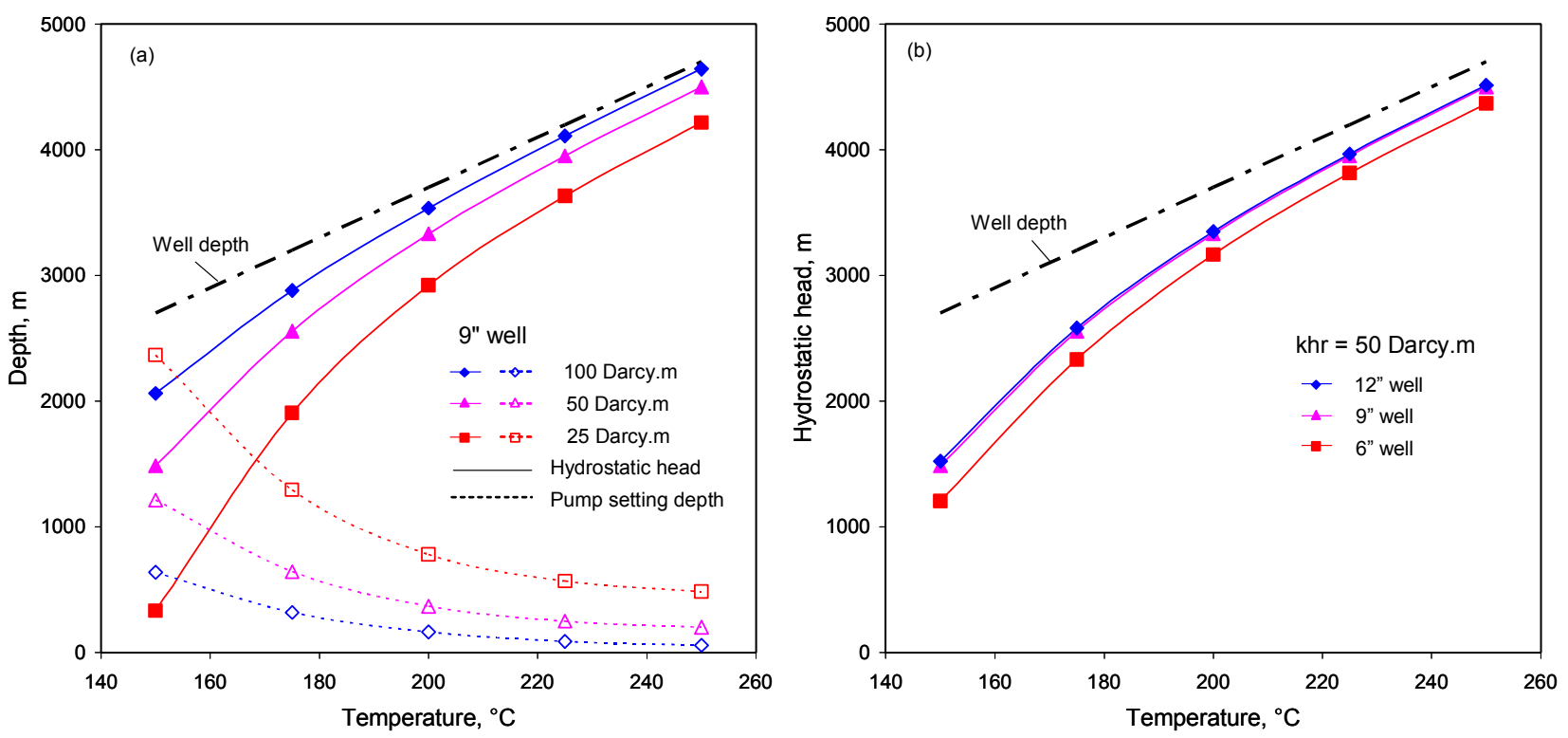

Figure 5. Hydrostatic head and pump setting depth at different temperatures. 

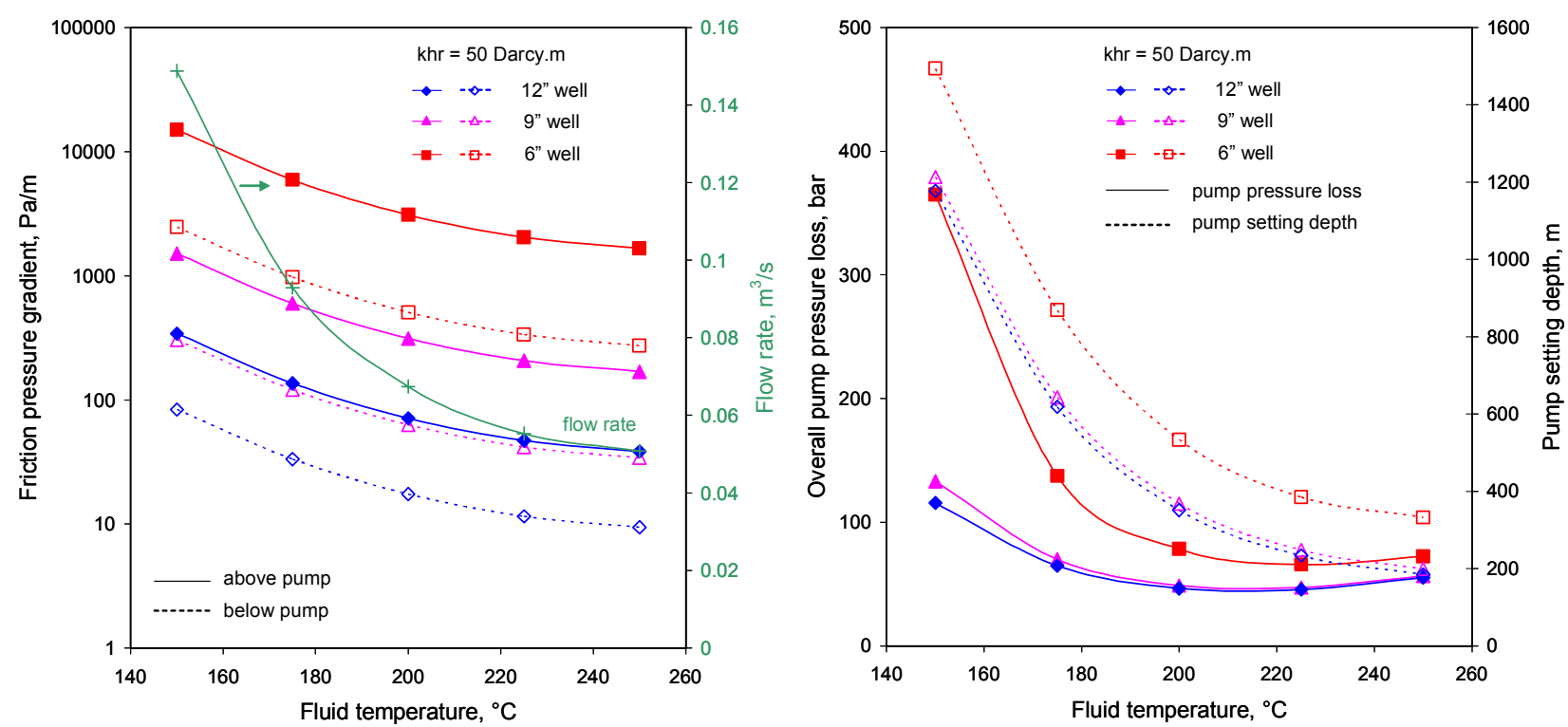

Figure 6. Friction pressure gradient and pump pressure loss at different temperatures.

The hydrostatic head and pump setting depth for different $k h_{r}$ and well size are plotted in Figure 5, where the pump setting depth is the difference between the well depth and hydrostatic head. Higher $k h_{r}$ results in a higher hydrostatic head and, therefore, smaller pump setting depth. When $k h_{r}$ is constant, the hydrostatic head for the 9- and 12-in. wells are almost identical, and that of 6-in. well a little lower. Since hydrostatic force is not affected by well size, friction force is the only factor to affect change. As indicated in Equation (12), the friction pressure gradient increases as flow rate increases (fluid temperature decreases) and flow diameter decreases. Figure 6(a) shows that larger wells have smaller friction pressure gradients. The flow diameter is larger below the pump; the friction pressure gradient is smaller below the pump. Another interesting feature is that for all the wells, there is a minimum overall pump pressure loss at about $200^{\circ} \mathrm{C}$ [Figure 6(b)]. This is caused by the balance between hydrostatic pressure loss and friction pressure loss. The power plant is the most efficient at about this point.

Figures A-4 through A-9 show the results for designed gross power plants of 2.5, 7.5, and $10 \mathrm{MWe}$, which reflect the features of 5-MWe gross power. As the designed power increases, the effect of $k h_{r}$ increases on pump setting depth and pump pressure loss, especially in the low fluid temperature range. The hydrostatic head decreases as the designed power increases. Comparing Figures A-4(b), A-6(b), and A-8(b), the difference between the 9-and 12-in. wells is very small, but the 6-in. well is affected more severely.

Figure 7 shows the pump setting depth for all four different designed power produced from a 9-in. well at a defined $k h_{r}$. The pump setting depth increases swiftly as fluid temperature decreases, especially for higher designed power. The hydrostatic pressure loss for all the cases is the same. The pressure loss caused by friction increases as temperature decreases when fluid temperature is less than $200^{\circ} \mathrm{C}$. The pressure loss by friction is not very sensitive in the high temperature range. 

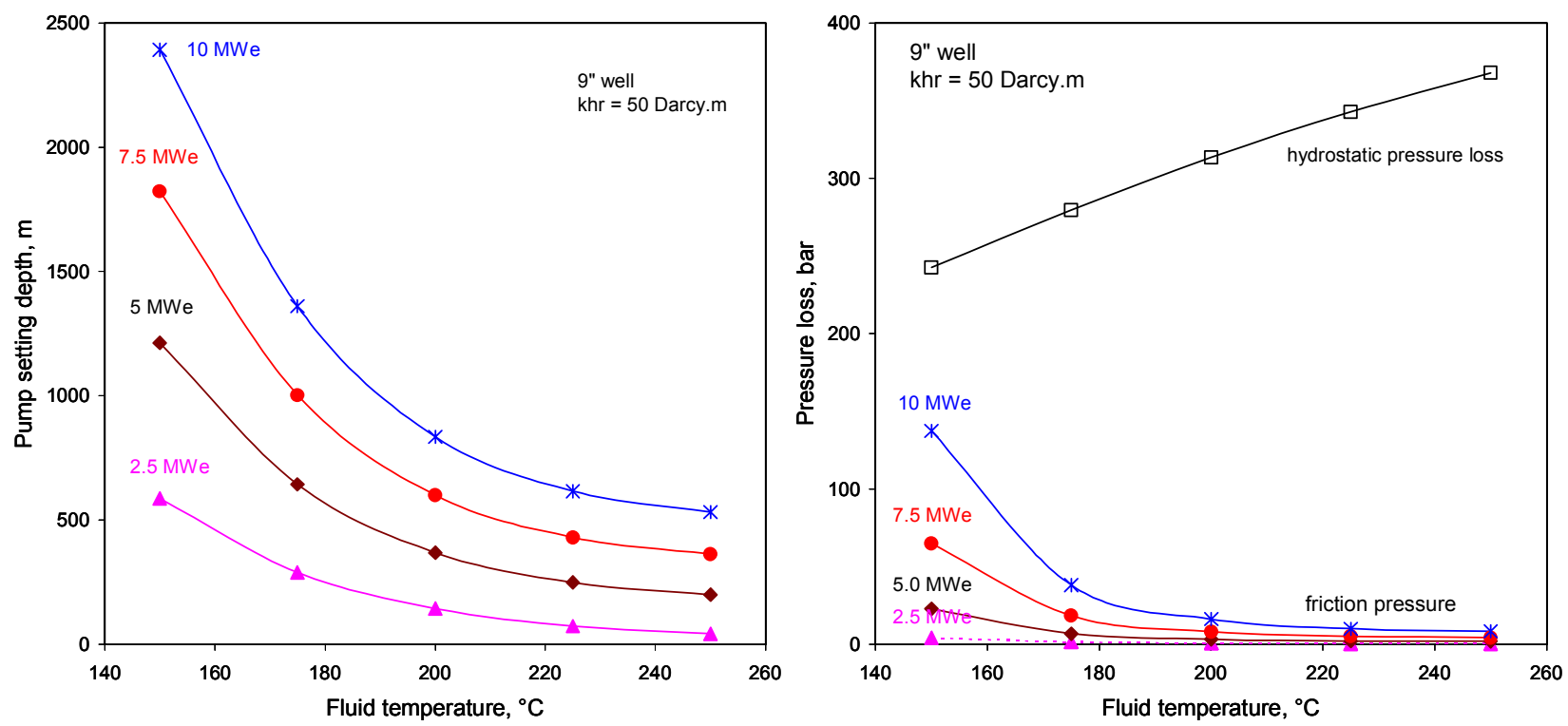

Figure 7. Pump setting depth and overall pressure loss for the 9-in. well.

\subsection{Constant Flow Rate (Submersible Pump)}

If the fluid flow rate is a constant for different temperature cases, according to Figure 2 the power generated will be different. The pump setting depth and the friction loss will also be different for wells with different sizes. The flow rate for a 5-MWe power plant at $200^{\circ} \mathrm{C}$ is selected in order to analyze the related effects $\left(q=0.06742 \mathrm{~m}^{3} / \mathrm{s}\right)$.

For constant flow rates, the friction pressure gradients for a specific well vary only slightly with temperature change (because of fluid density change due to temperature change). Comparing 9- and 12-in. wells, the 6-in. well has greatest friction pressure gradient and overall pressure loss. Net power generation at a specific temperature is only slightly affected by well size and $k h_{r}$ in the 25-100 Darcy.m range (Figure 9). This clearly indicates that higher hydraulic conductivity results in lower power consumption and higher net power generation in wells of different sizes.

Since the friction loss is a small portion of the power consumption, and hydrostatic loss per unit depth is not related to well size, the well size is not a major factor in the performance of larger wells. The decreasing net power with decreasing temperature reflects the decrease in brine effectiveness with temperature; at constant flow rate, power plant output decreases with the decrease of brine effectiveness. Overall, the net power production is not a strong function of the well size, though pumping losses increase at lower resource temperatures. 

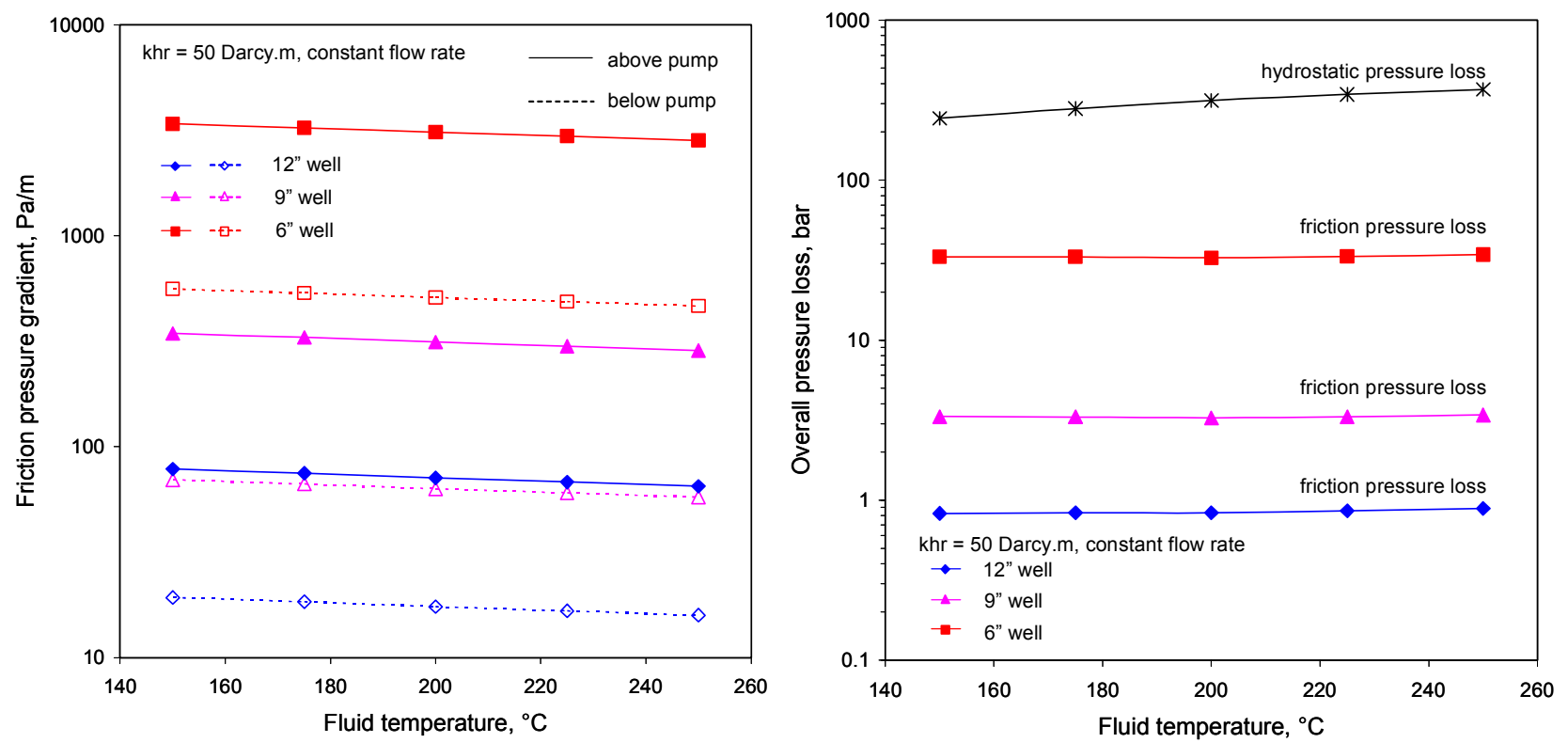

Figure 8. Pressure loss at constant flow rate.
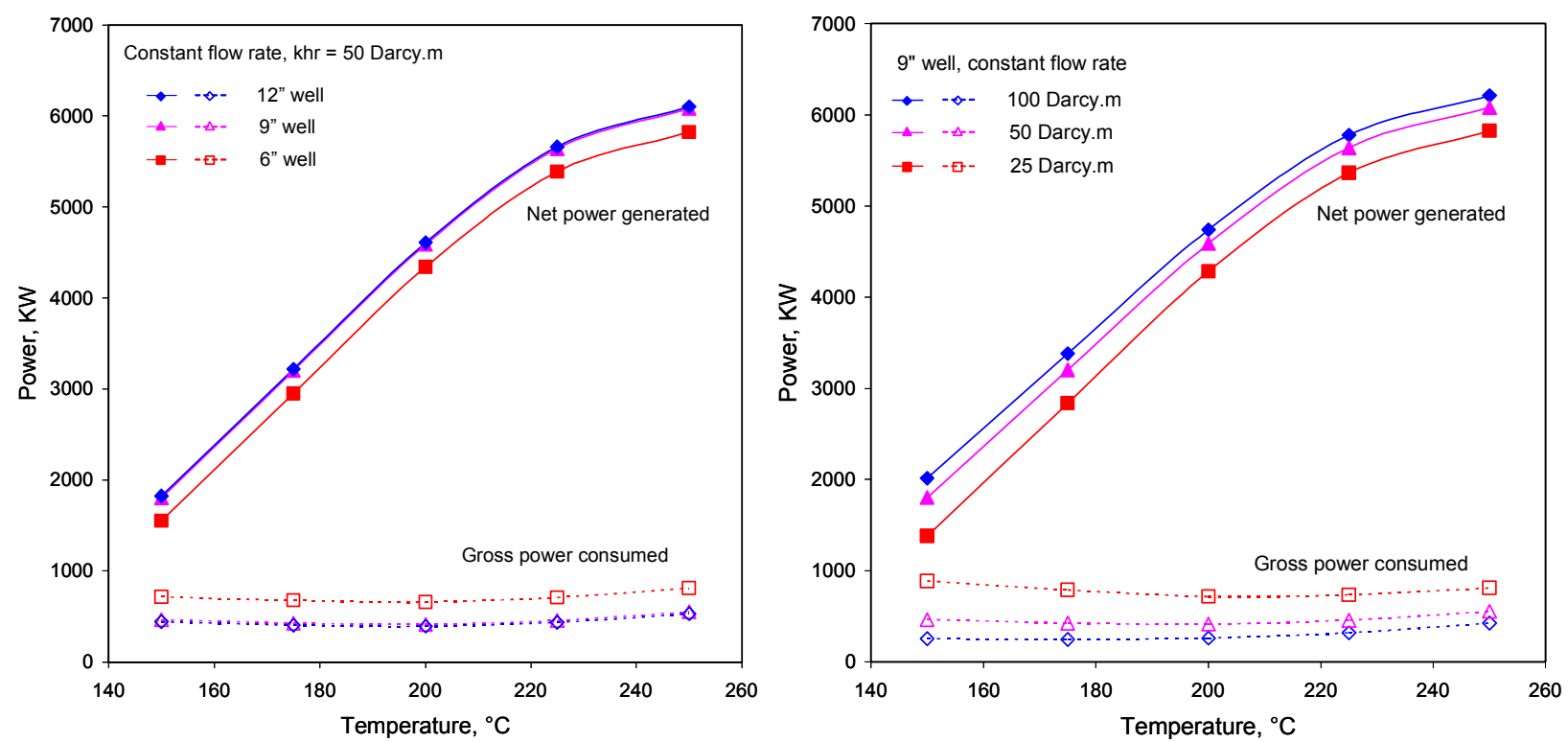

Figure 9. Power generation at constant flow rate for different $k h_{r}$ and wells with different sizes.

\subsection{Constant Gross Power Generation (Lineshaft Pump)}

Usually, the maximum flow rate and submerge depth for a lineshaft pump are considered $0.1262 \mathrm{~m}^{3} / \mathrm{s}$ and $426 \mathrm{~m}$, respectively. And only one pump can be used in the wellbore. Because of these limitations, lineshaft pumps can be used only in certain conditions. Of the example cases listed in Table 1, results calculated for those cases in which a lineshaft pump can be used are listed in Tables 3 through 5. In those cases in which the lineshaft pump cannot be used, either the required pump setting depth is over the limitation, or a single pump is inadequate to lift the liquid column. Results indicate that a lineshaft pump can be used in most cases in the high-temperature range for a 2.5-MWe power plant (Table 3). For a 5-MWe power plant, a lineshaft pump can be used only for high hydraulic conductivity 
for 9- and 12-in. wells (Table 4). For a 7.5-MWe power plant, a lineshaft pump can be used in only a very few cases (Table 5). For a 10-MWe power plant, no lineshaft pump can be used in any of the cases, because the required flow rate exceeds the limitations.

Table 3. Lineshaft pump used for a 2.5-MWe power plant.

\begin{tabular}{ccccccl}
\hline Well & $k h_{r}$ & \multicolumn{5}{c}{ Fluid Temperature $\left({ }^{\circ} \mathrm{C}\right)$} \\
\cline { 3 - 6 } Size & (Darcy.m) & 150 & 175 & 200 & 225 & 250 \\
\hline \multirow{2}{*}{6 in. } & 100 & no & yes & yes & yes & yes \\
& 50 & no & no & yes & yes & yes \\
& 25 & no & no & yes & yes & yes \\
\hline \multirow{2}{*}{9 in. } & 100 & yes & yes & yes & self-lift & self-lift \\
& 50 & no & yes & yes & yes & yes \\
& 25 & no & no & no & yes & yes \\
\hline \multirow{2}{*}{12 in. } & 100 & yes & yes & yes & self-lift & self-lift \\
& 50 & no & yes & yes & yes & yes \\
& 25 & no & no & yes & yes & yes \\
\hline
\end{tabular}

No: the required setting depth is too high for a lineshaft pump.

Yes: one lineshaft pump is used.

Self-lift: no pump is necessary.

Table 4. Lineshaft pump used for a 5-MWe power plant.

\begin{tabular}{|c|c|c|c|c|c|c|}
\hline \multirow{2}{*}{$\begin{array}{l}\text { Well } \\
\text { Size }\end{array}$} & \multirow{2}{*}{$\begin{array}{c}k h_{r} \\
\text { (Darcy.m) }\end{array}$} & \multicolumn{5}{|c|}{ Fluid Temperature $\left({ }^{\circ} \mathrm{C}\right)$} \\
\hline & & 150 & 175 & 200 & 225 & 250 \\
\hline \multirow{3}{*}{$6 \mathrm{in.}$} & 100 & no & no & no & no & no \\
\hline & 50 & no & no & no & no & no \\
\hline & 25 & no & no & no & no & no \\
\hline \multirow{3}{*}{$9 \mathrm{in.}$} & 100 & no & no & yes & self-lift & self-lift \\
\hline & 50 & no & no & yes & yes & yes \\
\hline & 25 & no & no & no & no & no \\
\hline \multirow{3}{*}{$12 \mathrm{in.}$} & 100 & no & yes & yes & yes & yes \\
\hline & 50 & no & no & yes & yes & yes \\
\hline & 25 & no & no & no & no & no \\
\hline
\end{tabular}

Table 5. Lineshaft pump used for a 7.5-MWe power plant.

\begin{tabular}{ccccccc}
\hline Well & $k h_{r}$ & \multicolumn{5}{c}{ Fluid Temperature $\left({ }^{\circ} \mathrm{C}\right)$} \\
\cline { 3 - 7 } Size & $($ Darcy.m) & 150 & 175 & 200 & 225 & 250 \\
\hline \multirow{2}{*}{6 in. } & 100 & no & no & no & no & no \\
& 50 & no & no & no & no & no \\
& 25 & no & no & no & no & no \\
\hline \multirow{2}{*}{9 in. } & 100 & no & no & no & yes & no \\
& 50 & no & no & no & no & no \\
& 25 & no & no & no & no & no \\
\hline \multirow{2}{*}{12 in. } & 100 & no & no & no & yes & yes \\
& 50 & no & no & no & yes & yes \\
& 25 & no & no & no & no & no \\
\hline
\end{tabular}




\subsection{Constant Flow Rate (Lineshaft Pump)}

Similar to the constant flow rate cases for submersible pumps, the required flow rate at $200^{\circ} \mathrm{C}$ for a specific power plant is selected for the calculation of lineshaft pump use. Considering the limitations of a lineshaft pump, the results are listed in Tables 6 and 7. For a 2.5-MWe power plant, a lineshaft pump can be used in most cases (Table 6). For a 5-MWe power plant, a lineshaft pump can be used in all cases for 9- and 12-in.wells when $k h_{r}=100$ Darcy.m, and can be used in some cases when $k h_{r}=50$ Darcy.m (Table 7). For a 7.5-MWe power plant, a lineshaft pump can be used only for a 12-in. well when $k h_{r}=100$ Darcy.m. And a lineshaft pump cannot be used for a 10-MWe power plant at all because of the required high flow rate.

Table 6. A lineshaft pump used for a constant flow rate (required flow rate for a 2.5-MWe power plant at $\left.200^{\circ} \mathrm{C}\right)$.

\begin{tabular}{lccllll}
\hline Well & $k h_{r}$ & \multicolumn{5}{c}{ Fluid Temperature $\left({ }^{\circ} \mathrm{C}\right)$} \\
\cline { 3 - 7 } Size & Darcy.m & 150 & 175 & 200 & 225 & \multicolumn{1}{c}{250} \\
\hline \multirow{2}{*}{6 in. } & 100 & yes & yes & yes & yes & yes \\
& 50 & yes & yes & yes & yes & yes \\
& 25 & no & no & yes & no & no \\
\hline \multirow{2}{*}{9 in. } & 100 & yes & yes & yes & yes & self-lift \\
& 50 & yes & yes & yes & yes & yes \\
& 25 & no & no & no & yes & yes \\
\hline \multirow{2}{*}{12 in. } & 100 & yes & yes & yes & yes & self-lift \\
& 50 & yes & yes & yes & yes & yes \\
& 25 & no & no & yes & yes & yes \\
\hline
\end{tabular}

Table 7. Lineshaft pump used for a constant flow rate (required flow rate for a 5-MWe power plant at $\left.200^{\circ} \mathrm{C}\right)$.

\begin{tabular}{lclllll}
\hline Well & $k h_{r}$, & \multicolumn{5}{c}{ Fluid temperature $\left({ }^{\circ} \mathrm{C}\right)$} \\
Size & Darcy.m & 150 & 175 & 200 & 225 & 250 \\
\hline \multirow{2}{*}{6 in. } & 100 & no & no & no & no & no \\
& 50 & no & no & no & no & no \\
& 25 & no & no & no & no & no \\
\hline \multirow{2}{*}{9 in. } & 100 & yes & yes & yes & yes & yes \\
& 50 & no & no & no & no & no \\
& 25 & no & no & no & no & no \\
\hline \multirow{2}{*}{12} & 100 & yes & yes & yes & yes & yes \\
in. & 50 & no & no & yes & yes & yes \\
\hline
\end{tabular}




\section{Conclusions and Summary}

Geothermal power projects usually have high capital investment for exploration, drilling wells, and installation of plant but low operating costs. To meet the low cost expectation, geothermal well design is critical. As shown in this report, performance of the wells is determined by the hydrothermal reservoir properties and well size. Higher hydraulic conductivity results in lower artificial lifting power consumption. A reservoir with a higher temperature can produce more power, but-from drilling to operation and maintenance-it costs more because of deeper depths that may be encountered to reach those higher temperatures. Small wells can save drilling cost, but the performance may not be economical in some cases. Therefore, efficient and cost-effective well design will consider various factors, including reservoir properties and well dimensions.

The following factors need to be taken into consideration in future work: injection well performance, heat loss, pump performance limitations, temperature restrictions, and operation and maintenance cost. Since the solubility of certain dissolved solids is affected by fluid temperature, the surface operation temperature will be restricted in order to avoid scale problems. Power plant efficiency will be affected by this restriction. 


\section{References}

Beggs, H. D., 1991, Gas Production Operations, OGCI publications, Oil \& Gas Consultants International Inc., Tulsa, Oklahoma.

Pritchett, J. W., 2000, "Electrical Generating Capacities of Geothermal Slim Holes," Proceedings World Geothermal Congress, 2000, Kyushu, Tohoku, Japan, May 28-June 10, 2000.

Renewable Energy Access, 2005, “Geothermal Guide to Green Energy Production,” April 22, http://renewableenergyaccess.com/rea/news/story?id=26591 . 


\section{Nomenclature}

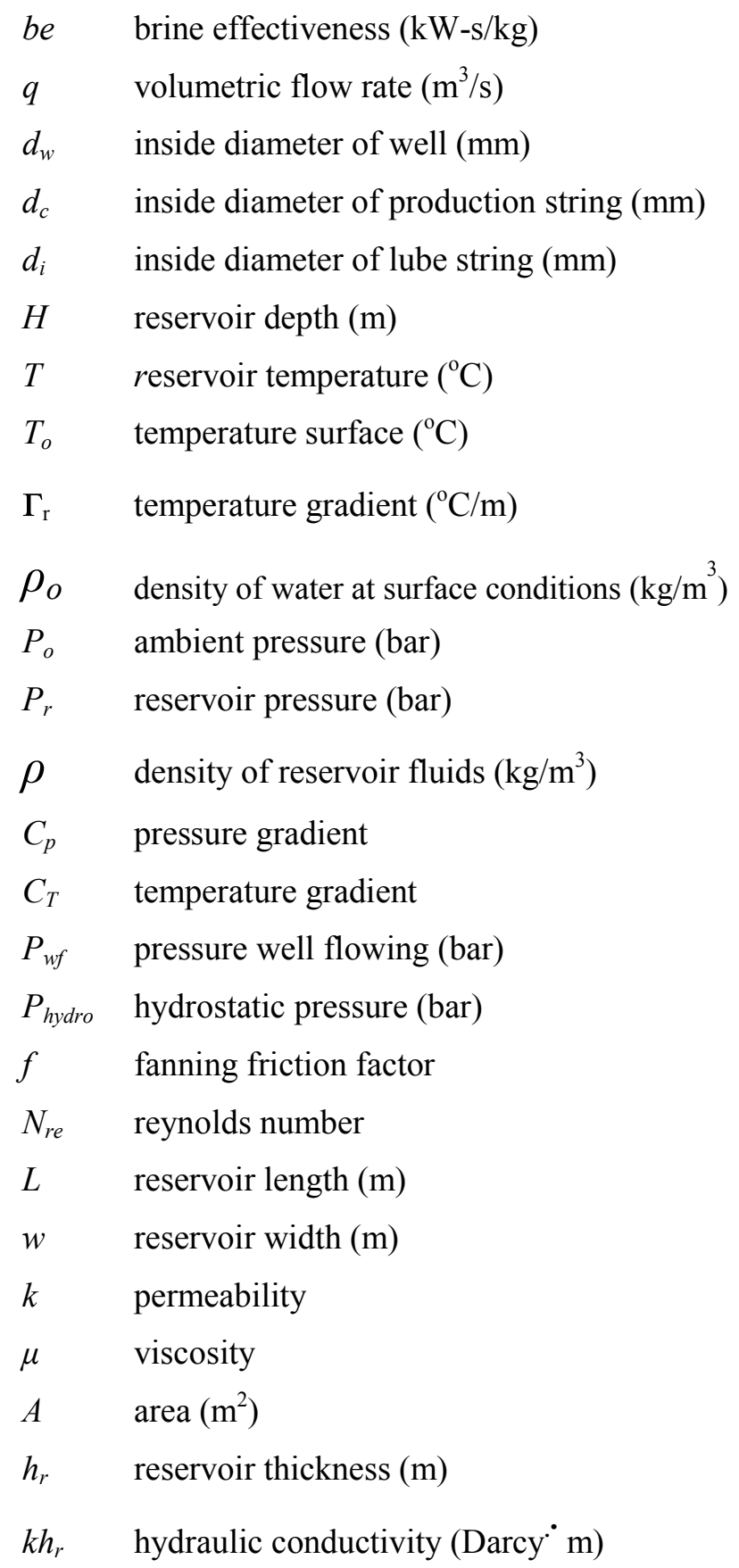


Appendix A

Constant Gross Power Generation

(submersible pump) 

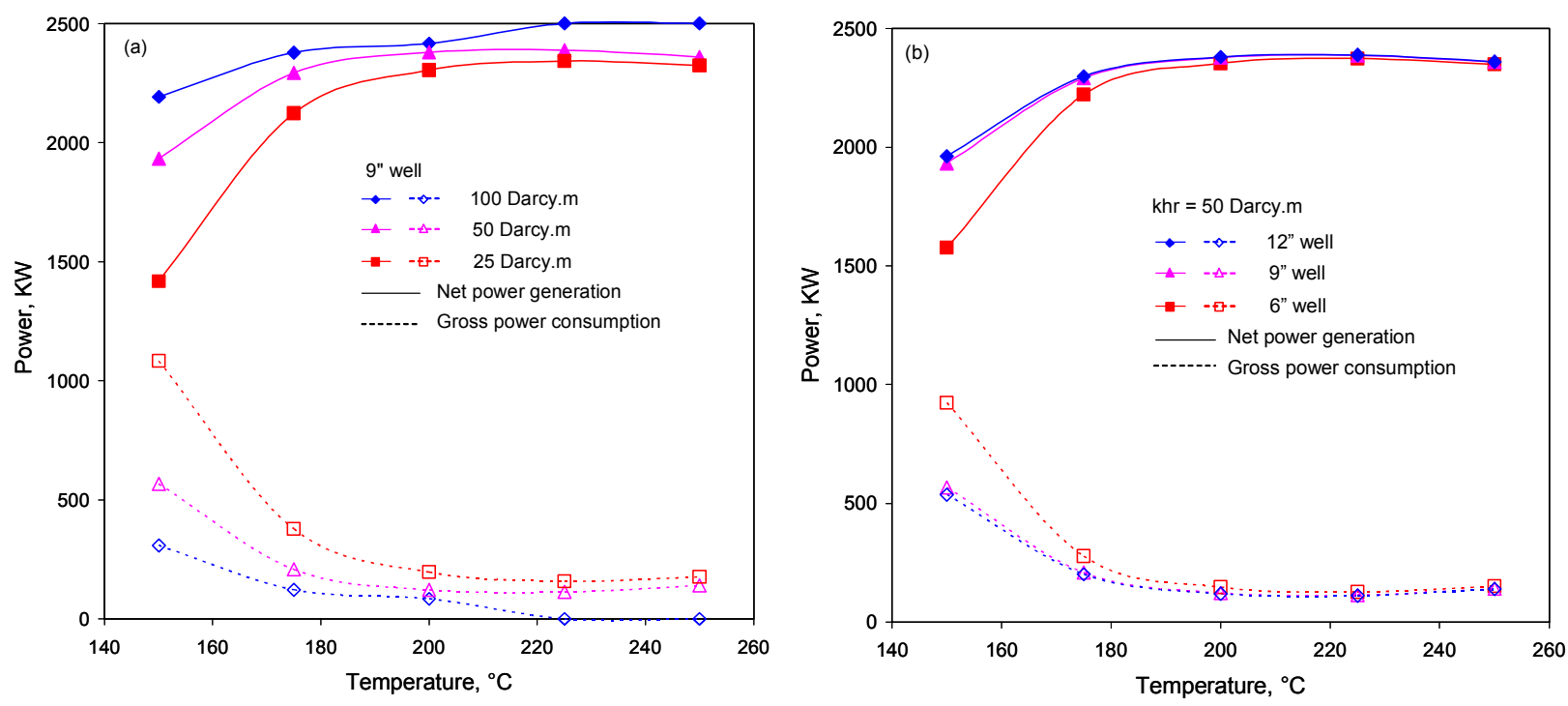

Figure A-1. The effect of well size and hydraulic conductivity on power production $(2.5 \mathrm{MWe})$.
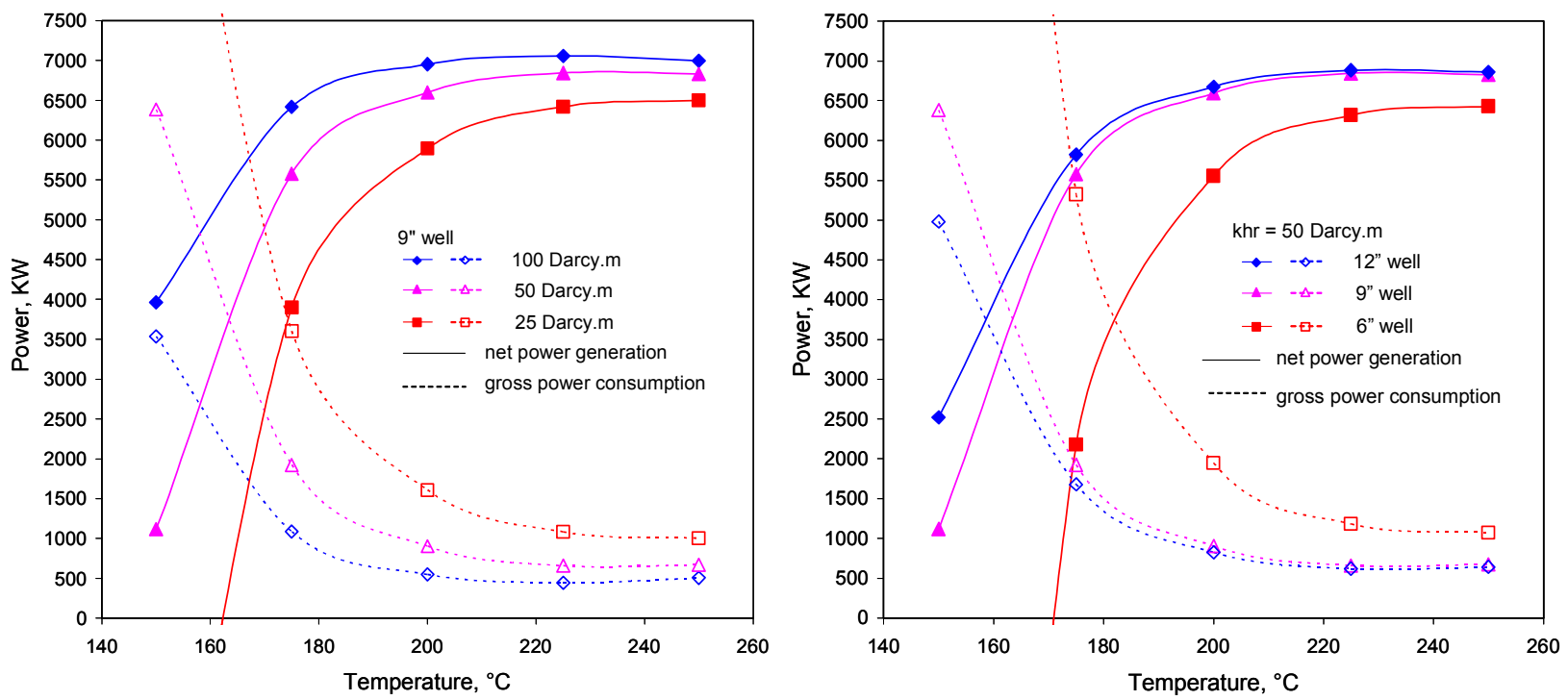

Figure A-2. The effect of well size and hydraulic conductivity on power production (7.5 MWe). 

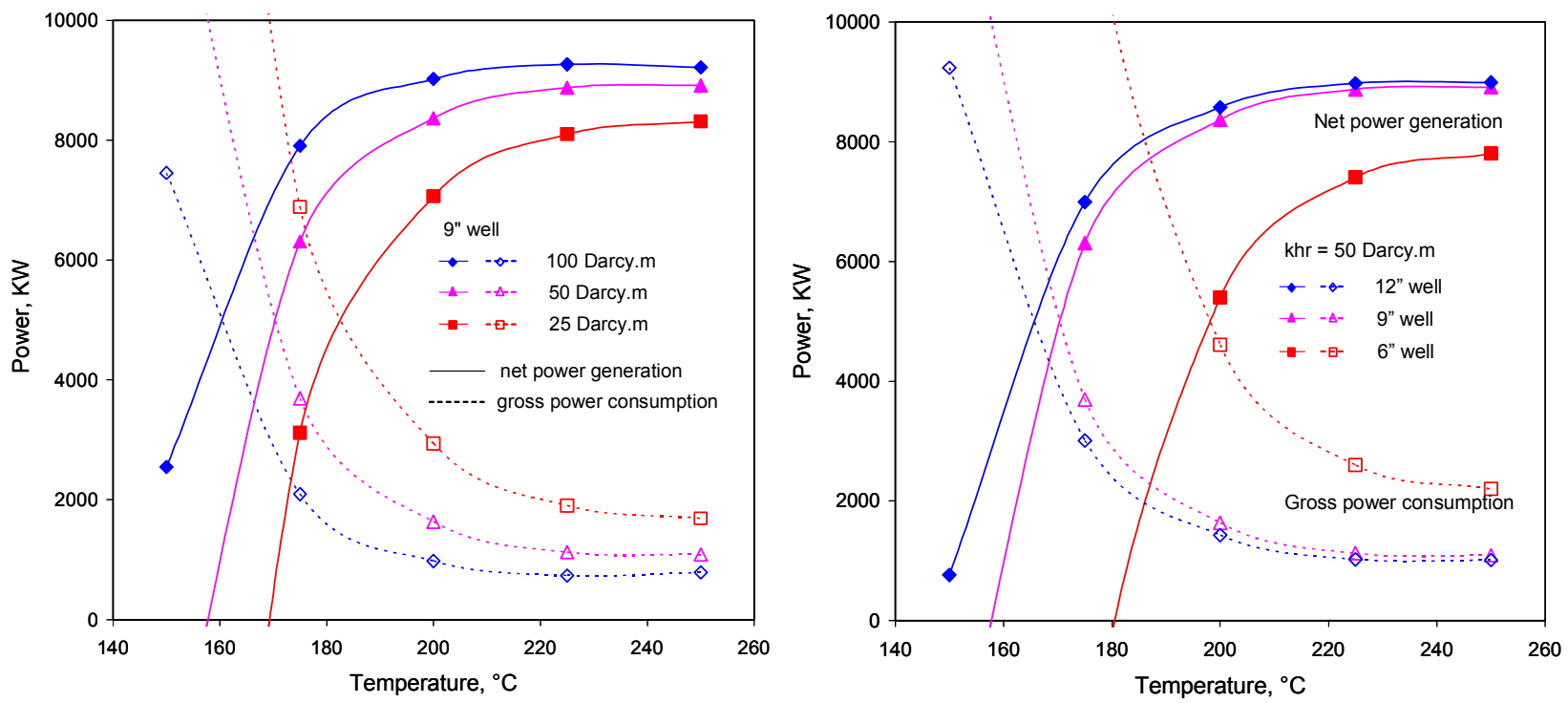

Figure A-3. The effect of well size and hydraulic conductivity on power production (10 MWe).
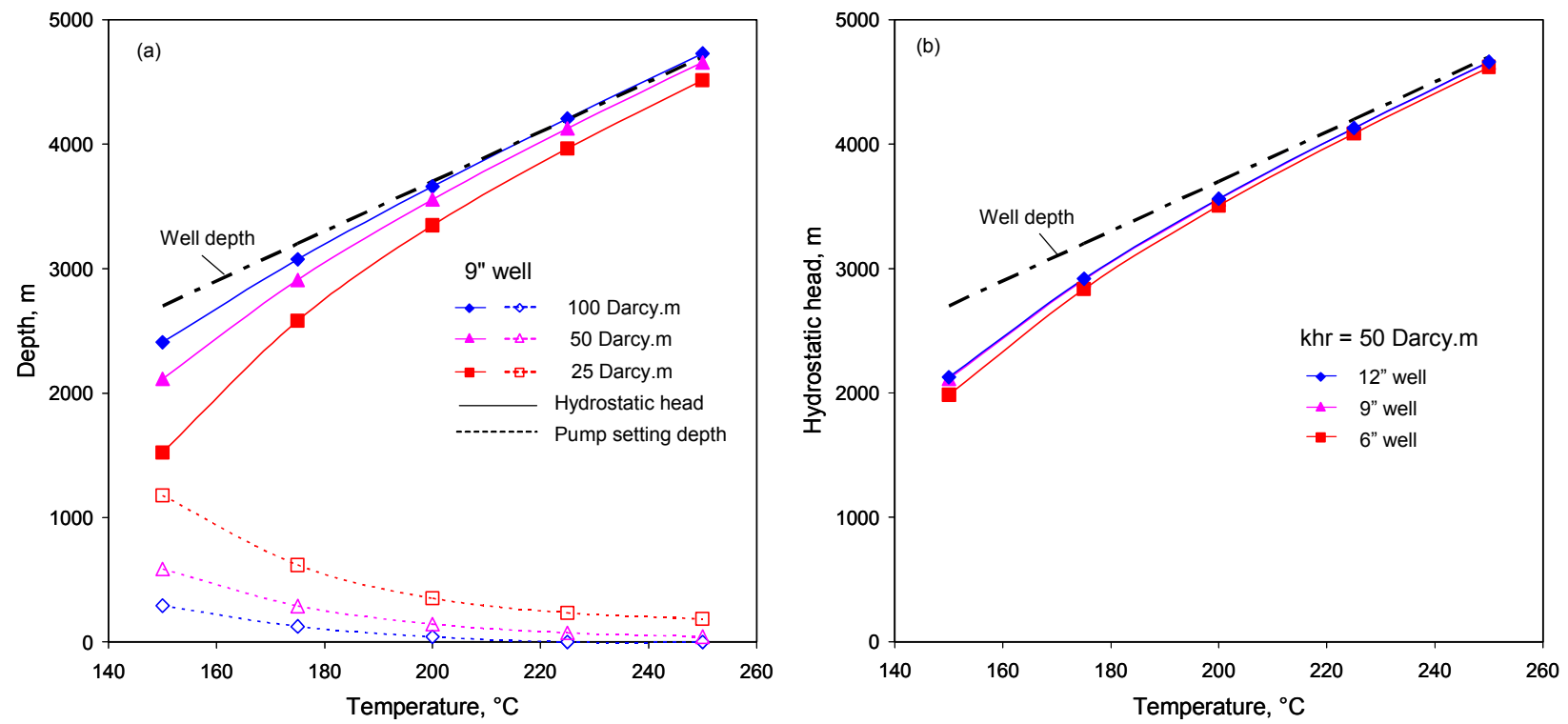

Figure A-4. Hydrostatic head and pump setting depth at different temperature for 2.5 MWe. 

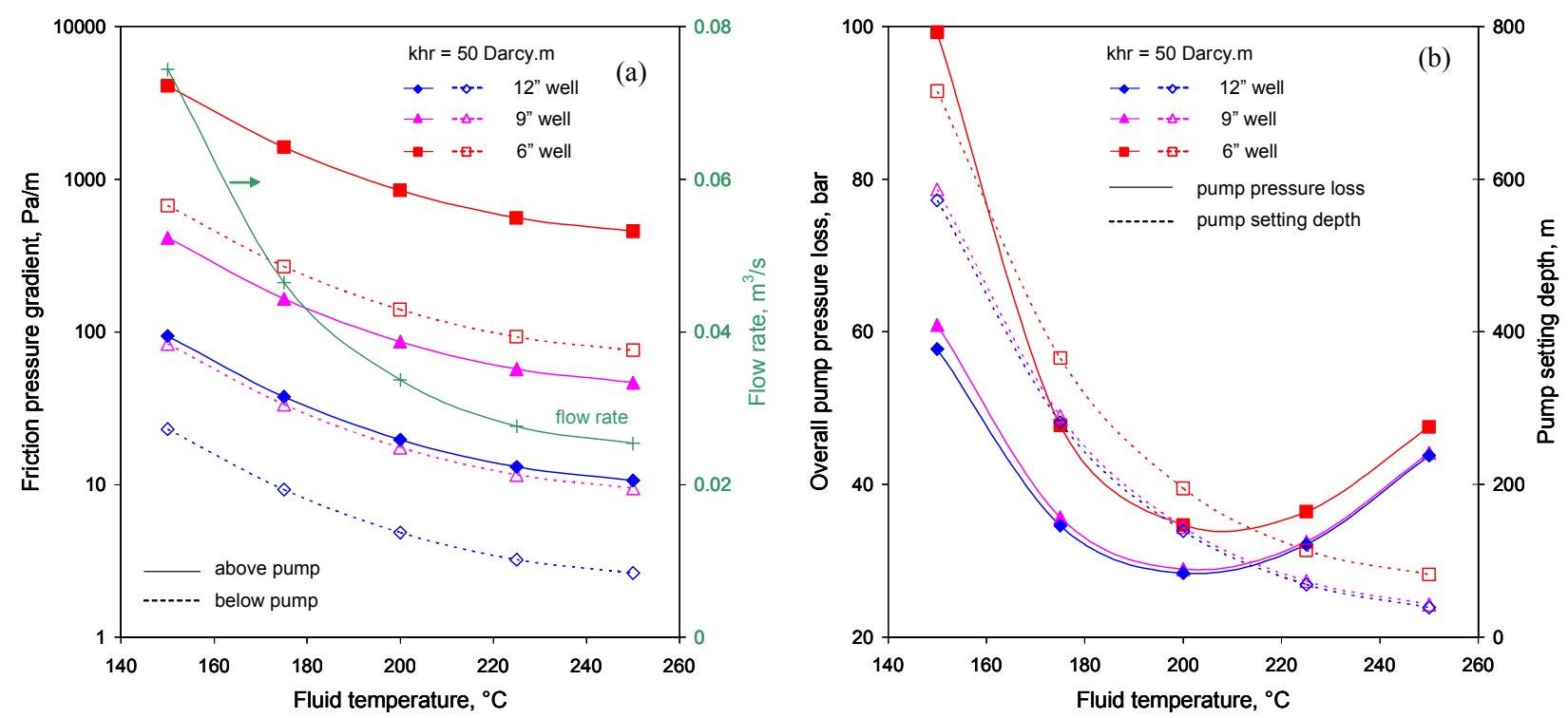

Figure A-5. Friction pressure gradient and pump pressure loss at different temperature for $2.5 \mathrm{MWe}$.
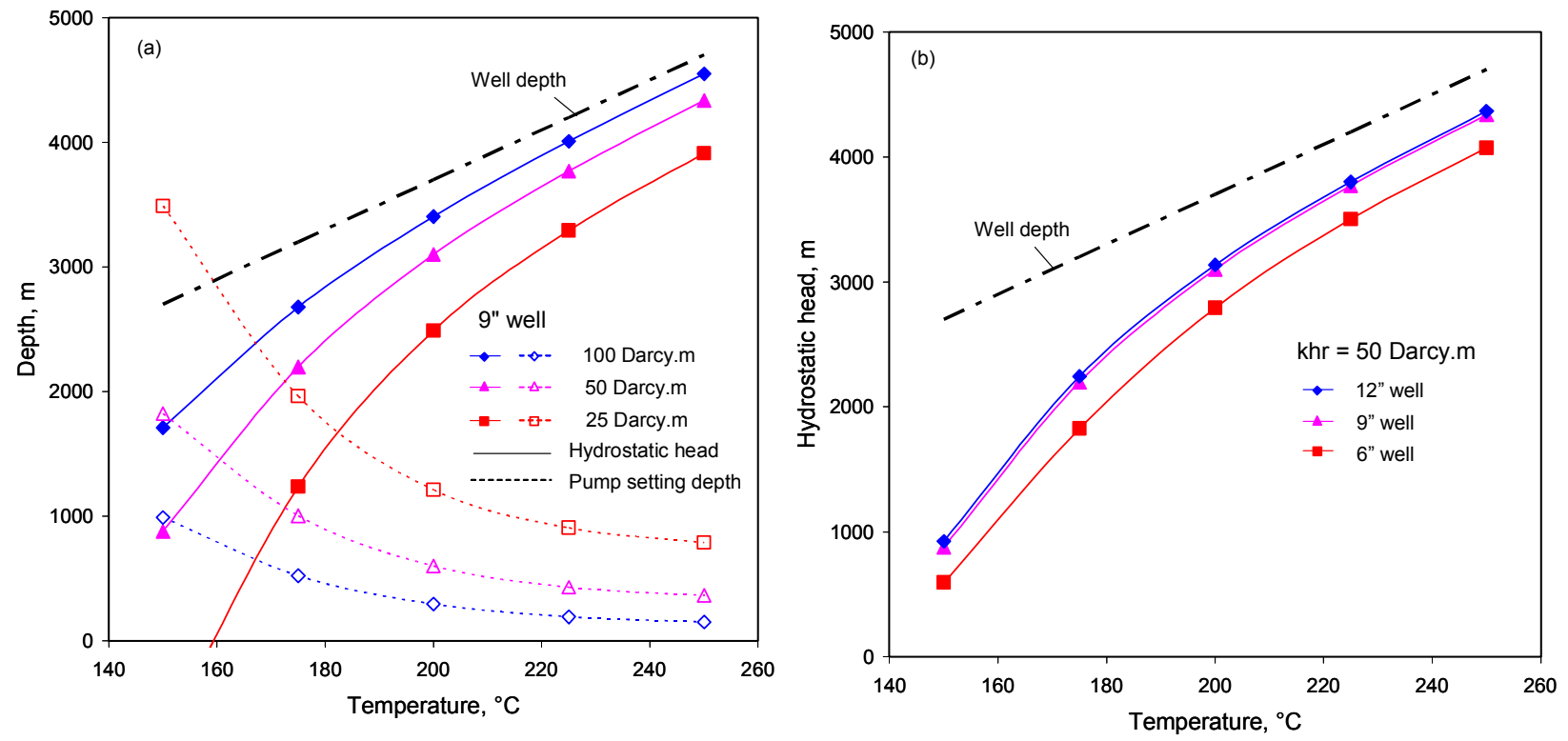

Figure A-6. Hydrostatic head and pump setting depth at different temperature for 7.5 MWe. 

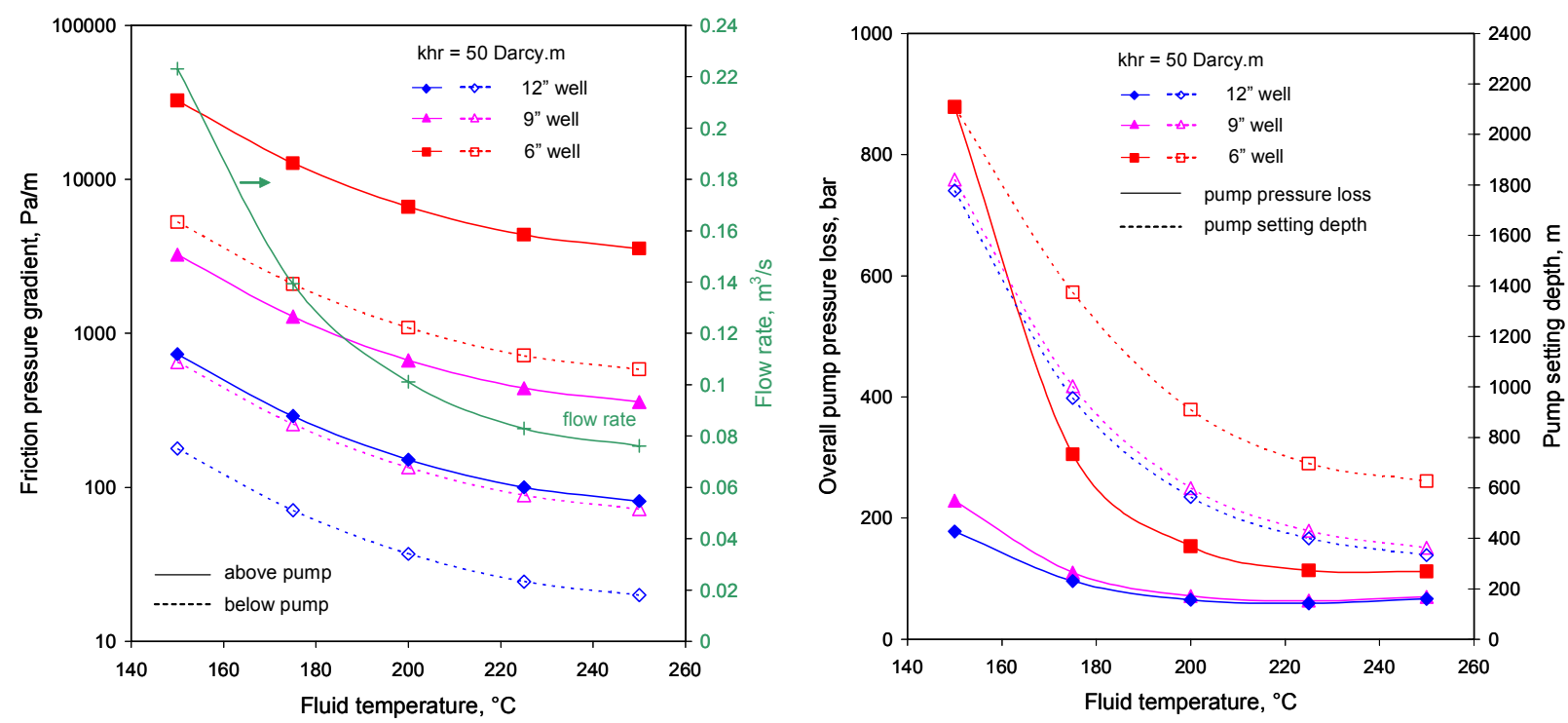

Figure A-7. Friction pressure gradient and pump pressure loss at different temperature for 7.5 MWe.
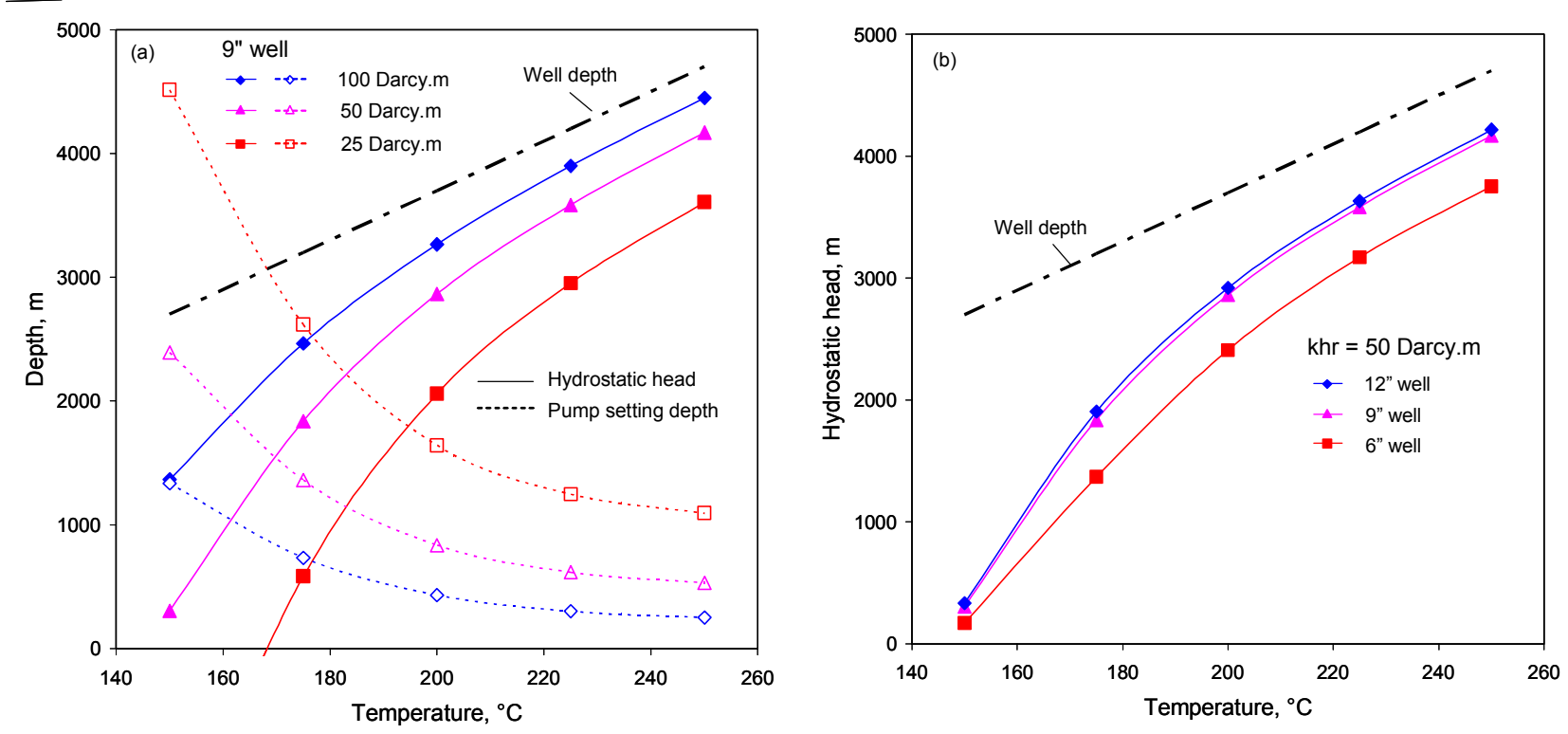

Figure A-8. Hydrostatic head and pump setting depth at different temperature for $10 \mathrm{MWe}$. 

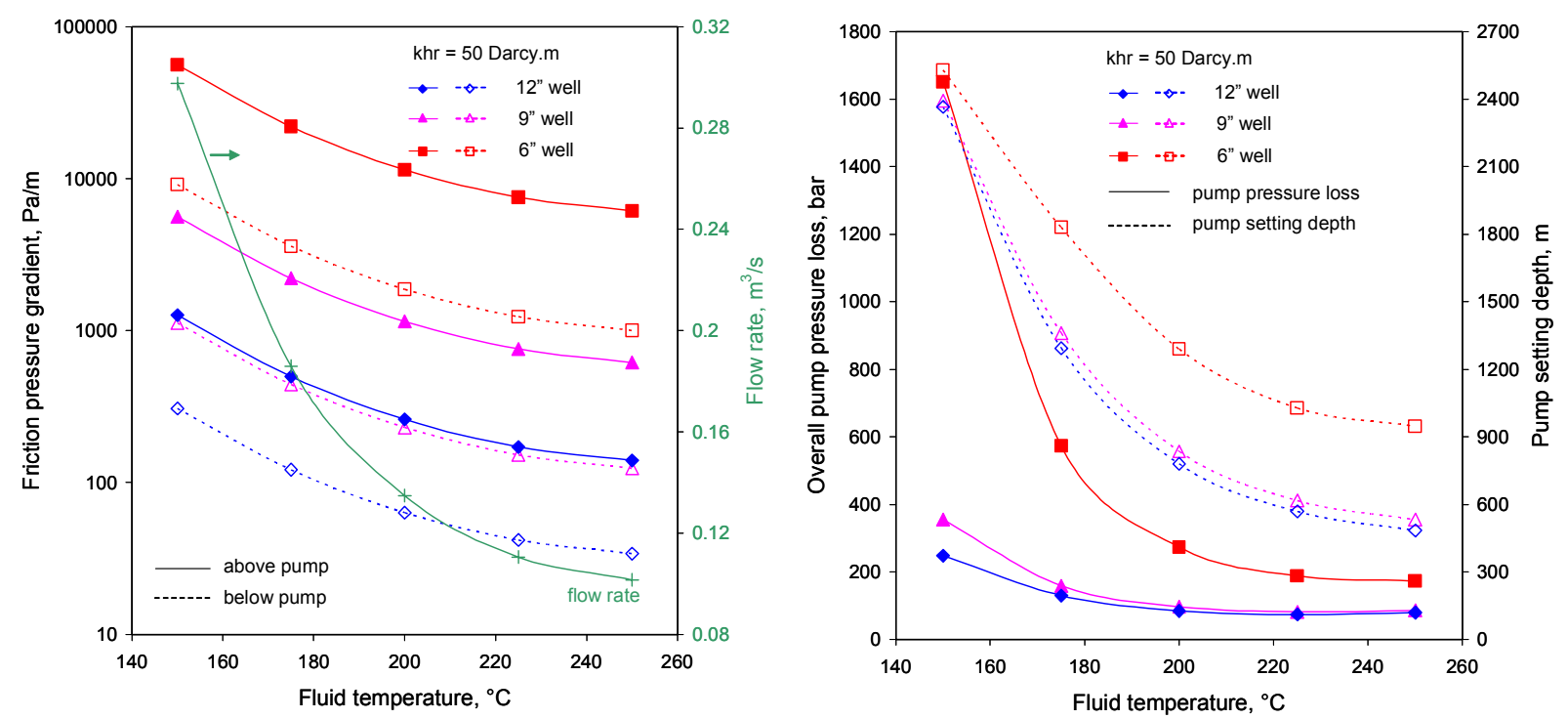

Figure A-9. Friction pressure gradient and pump pressure loss at different temperature for $10 \mathrm{MWe}$.

\section{A-1. Constant flow rate (submersible pump)}
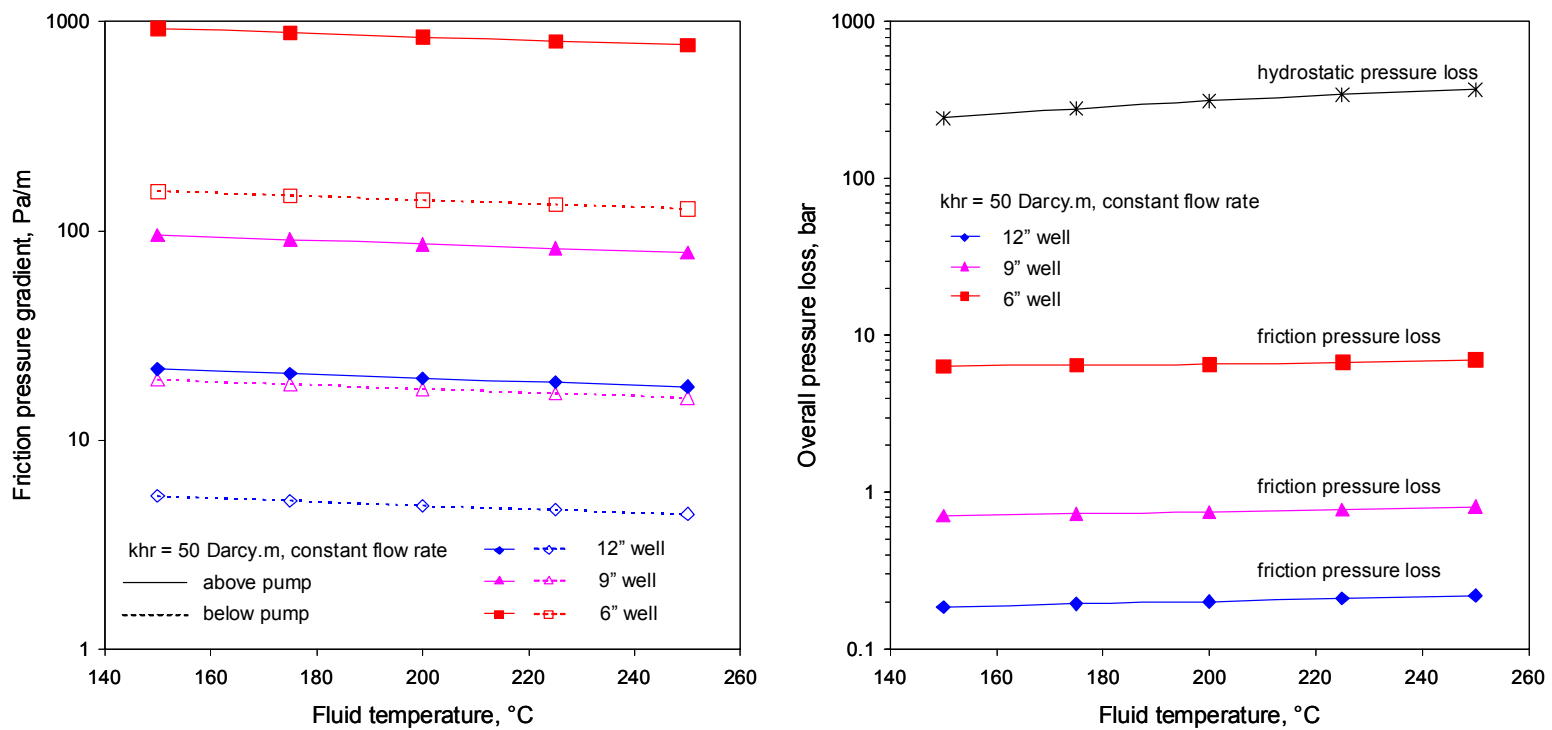

Figure A-10. Friction pressure gradient and overall pressure loss for constant flow rate (the required flow rate for producing $2.5 \mathrm{MWe}$ at $200^{\circ} \mathrm{C}$ ). 

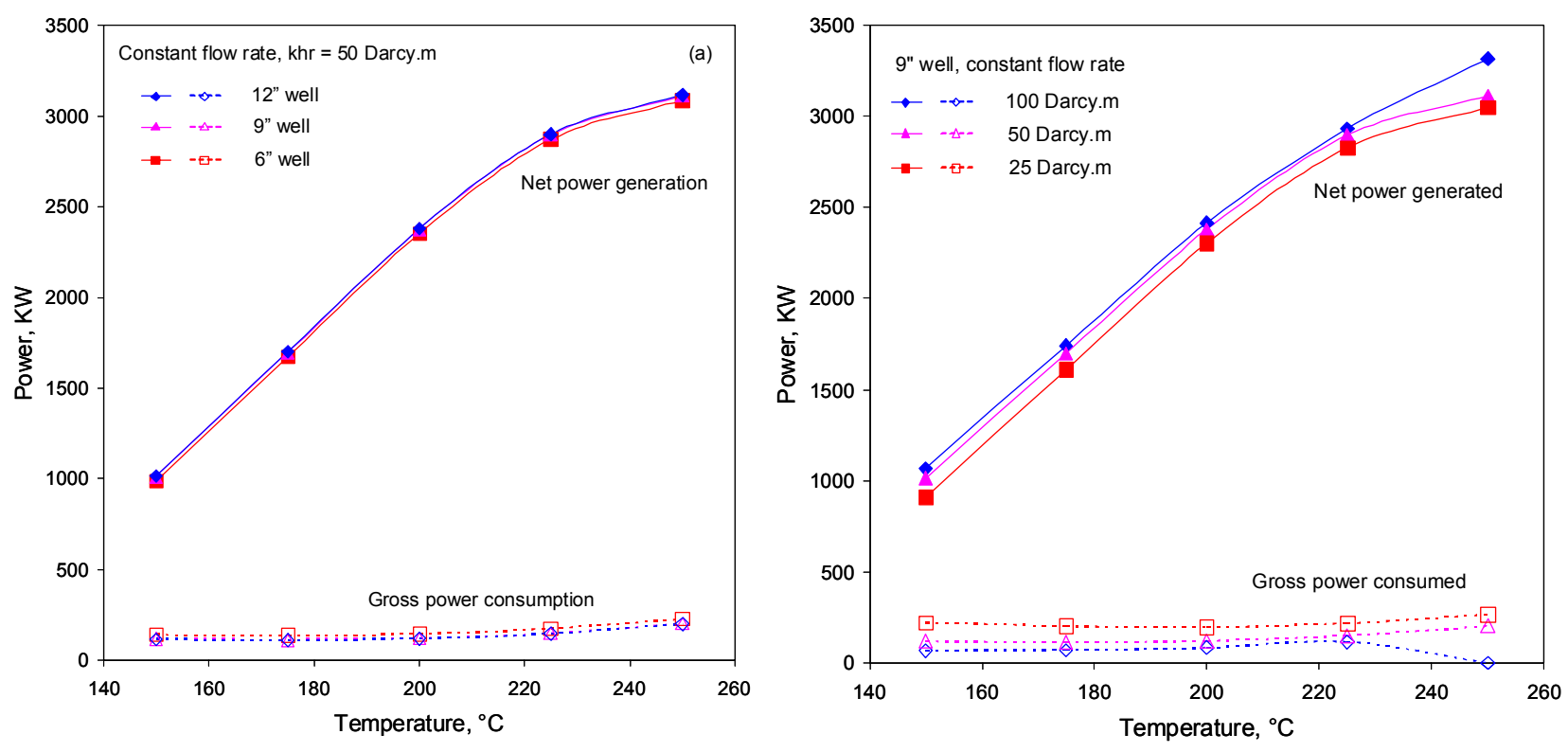

Figure A-11. Power generation and consumption at constant flow rate (the required flow rate for producing $2.5 \mathrm{MWe}$ at $200^{\circ} \mathrm{C}$ ).
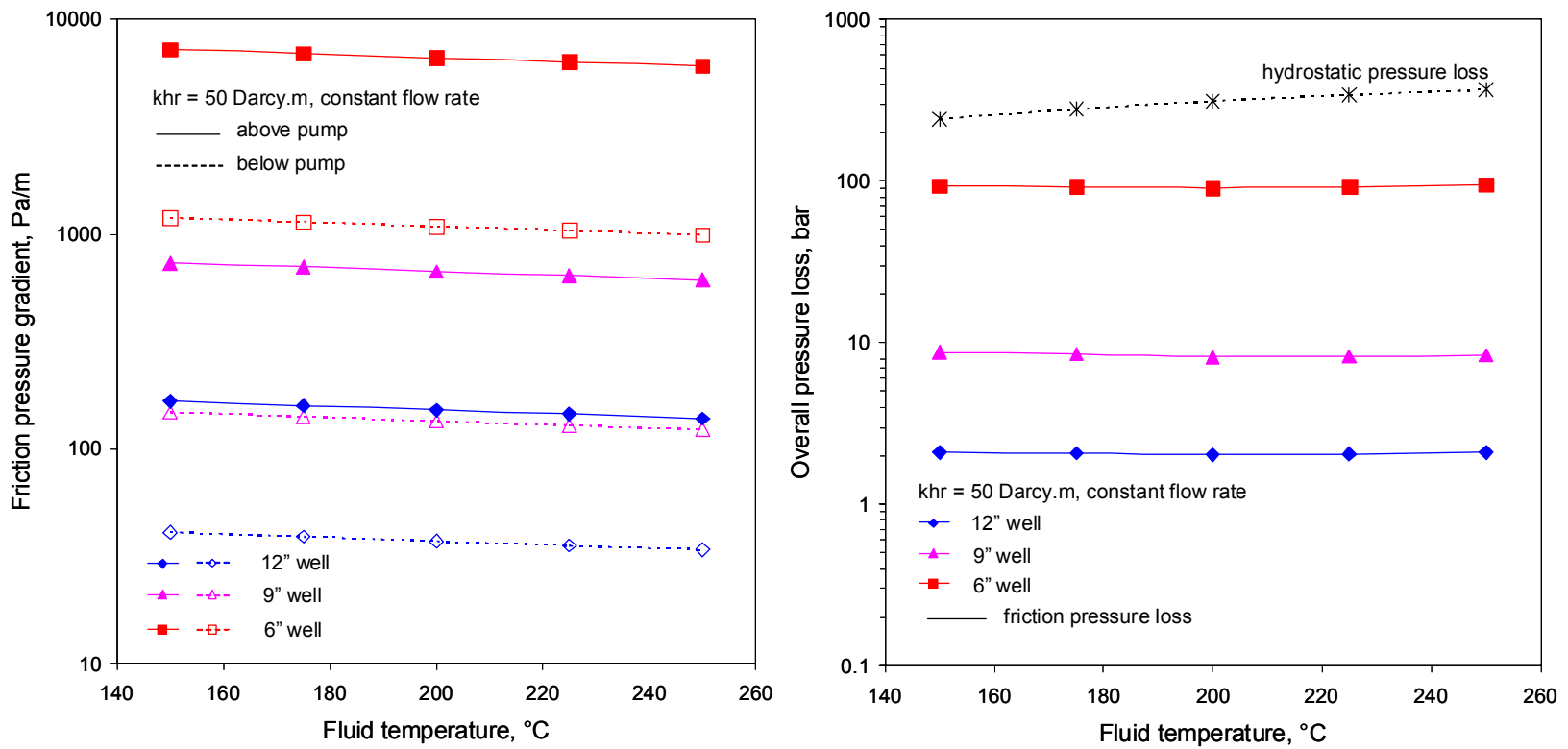

Figure A-12. Friction pressure gradient and overall pressure loss for constant flow rate (the required flow rate for producing $7.5 \mathrm{MWe}$ at $200^{\circ} \mathrm{C}$ ). 

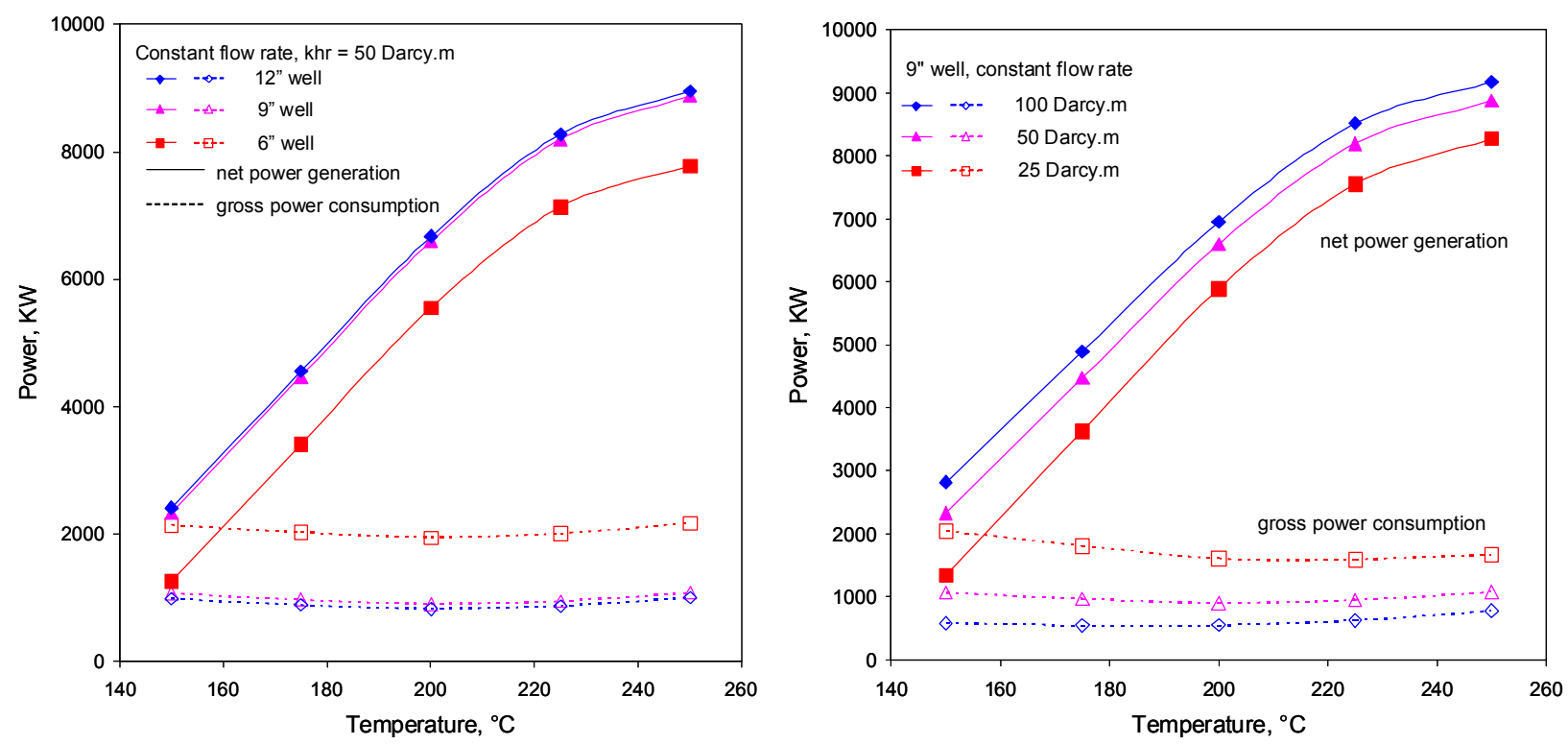

Figure A-13. Power generation and consumption at constant flow rate (the required flow rate for producing $7.5 \mathrm{MWe}$ at $200^{\circ} \mathrm{C}$ ).
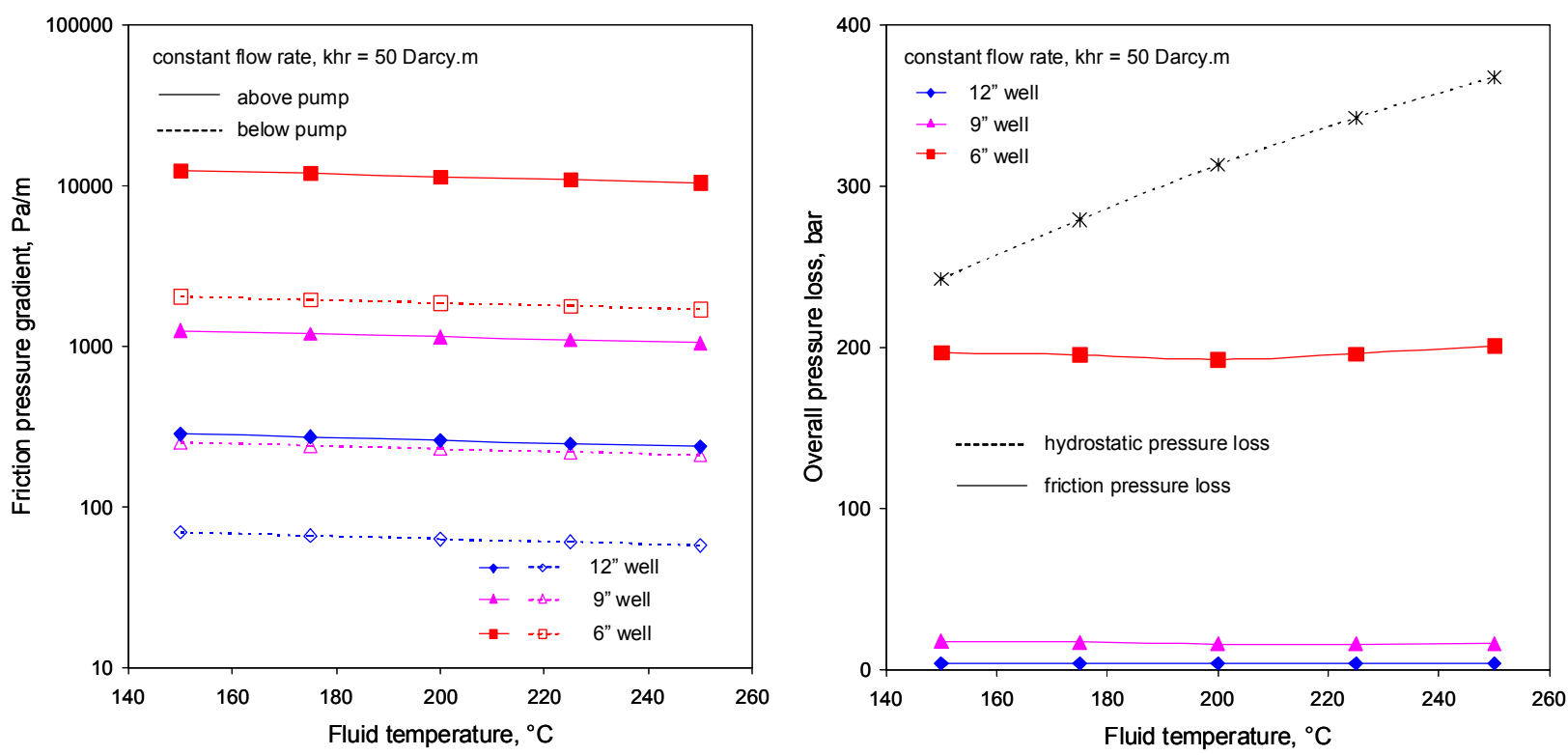

Figure A-14. Friction pressure gradient and overall pressure loss for constant flow rate (the required flow rate for producing $10 \mathrm{MWe}$ at $200^{\circ} \mathrm{C}$ ). 

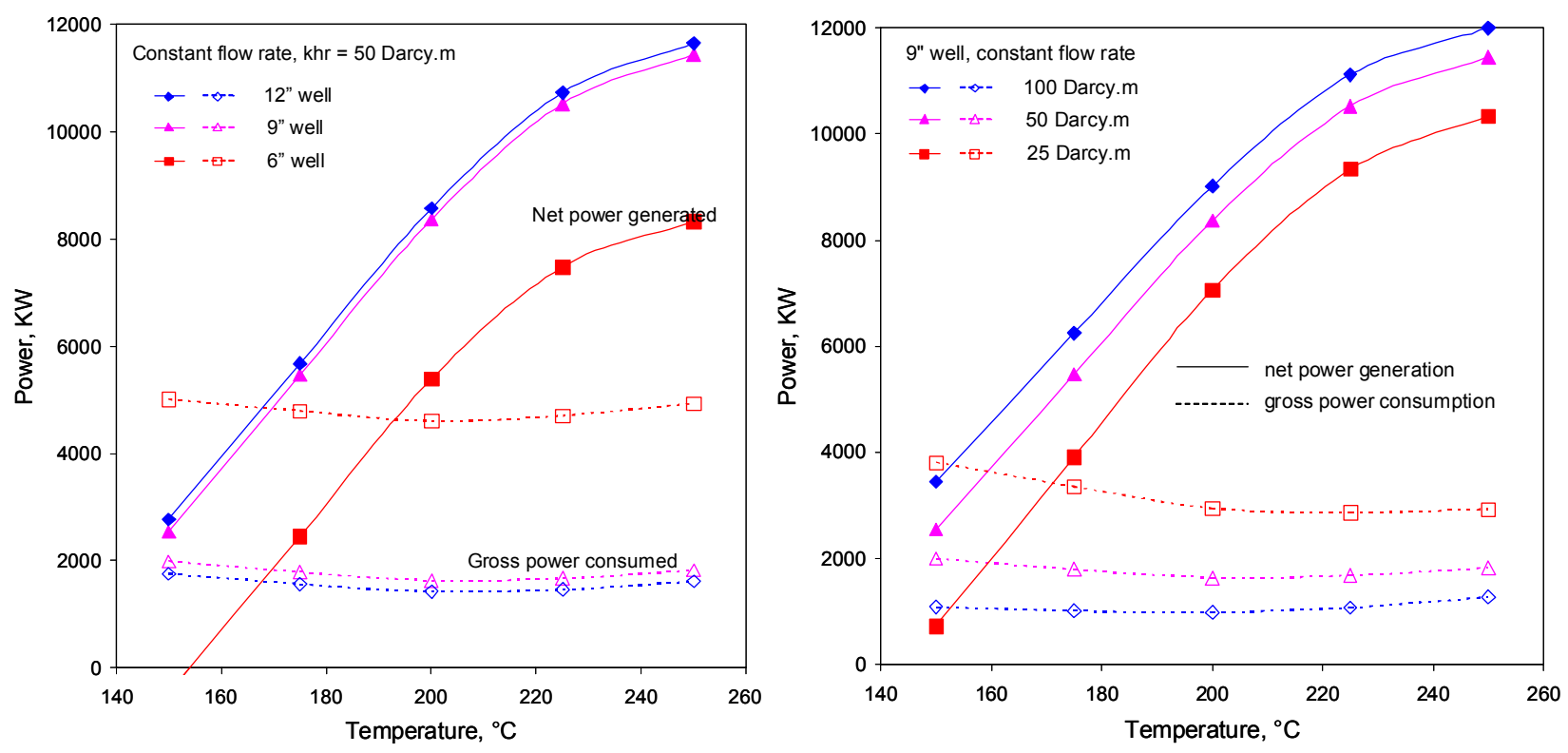

Figure A-15. Power generation and consumption at constant flow rate (the required flow rate for producing $10 \mathrm{MWe}$ at $200^{\circ} \mathrm{C}$ ). 